March 15, 2011

Hugh Davis, PhD

U.S. Department of Energy

SPRU Field Office SP23

2425 River Road

Niskayuna, New York 12309

\title{
SUBJECT: FINAL REPORT - INDEPENDENT VERIFICATION SURVEY ACTIVITIES AT THE SEPARATIONS PROCESS RESEARCH UNIT SITES, NISKAYUNA, NEW YORK - DCN 0496-SR-06-0
}

Dear Dr. Davis:

During the period of September 29, 2008 through August 25, 2010, the Oak Ridge Institute for Science and Education conducted verification survey activities of the Lower Level Land Area and North Field Project associated with the Separations Process Research Unit site. This final report consolidates the survey results from the previous five interim reports.

You may contact me via my information provided below or Phyllis Weaver at 865.576 .5321 should you have any questions or require additional information.

Sincerely,

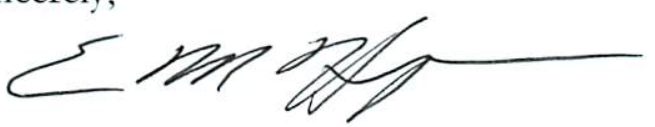

Evan M. Harpenau

Assistant Project Manager/Health Physicist

Independent Environmental Assessment and Verification

EMH:bf

Enclosure

$$
\text { c: } \quad \text { File } / 0496
$$

electronic distribution:

P. Weaver, (ORISE)

E. Bailey, (ORISE)

T. Vitkus, (ORISE)

S. Roberts, (ORISE) 


\title{
FINAL REPORT - INDEPENDENT
} VERIFICATION SURVEY ACTIVITIES AT THE SEPARATIONS PROCESS RESEARCH UNIT SITES, NISKAYUNA, NEW YORK

\author{
E. M. Harpenau
}

Prepared for the

U.S. Department of Energy

\section{O R I S E}

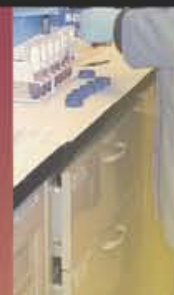

Oak Ridge Institute for Science and Education

Approved for public release; further dissemination unlimited. 
The Oak Ridge Institute for Science and Education (ORISE) is a U.S. Department of Energy institute focusing on scientific initiatives to research health risks from occupational hazards, assess environmental cleanup, respond to radiation medical emergencies, support national security and emergency preparedness, and educate the next generation of scientists. ORISE is managed by Oak Ridge Associated Universities.

\section{NOTICES}

The opinions expressed herein do not necessarily reflect the opinions of the sponsoring institutions of Oak Ridge Associated Universities.

This report was prepared as an account of work sponsored by the United States Government. Neither the United States Government nor the U.S. Department of Energy, nor any of their employees, makes any warranty, expressed or implied, or assumes any legal liability or responsibility for the accuracy, completeness, or usefulness of any information, apparatus, product, or process disclosed, or represents that its use would not infringe on privately owned rights. Reference herein to any specific commercial product, process, or service by trade name, mark, manufacturer, or otherwise, does not necessarily constitute or imply its endorsement or recommendation, or favor by the U.S. Government or any agency thereof. The views and opinions of authors expressed herein do not necessarily state or reflect those of the U.S. Government or any agency thereof. 


\title{
INDEPENDENT VERIFICATION SURVEY ACTIVITIES AT THE SEPARATIONS PROCESS RESEARCH UNIT SITES, NISKAYUNA, NEW YORK
}

\author{
Prepared by \\ Evan M. Harpenau \\ Oak Ridge Institute for Science and Education \\ Oak Ridge, Tennessee 37831-0117 \\ Prepared for the \\ U.S. Department of Energy
}

FINAL REPORT

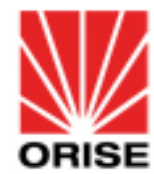

MARCH 2011

This report is based on work performed by the Oak Ridge Institute for Science and Education under contract number DE-AC05-06OR23100 with the U.S. Department of Energy 


\section{INDEPENDENT VERIFICATION SURVEY ACTIVITIES AT THE SEPARATIONS PROCESS RESEARCH UNIT SITES, NISKAYUNA, NEW YORK}

Prepared by:

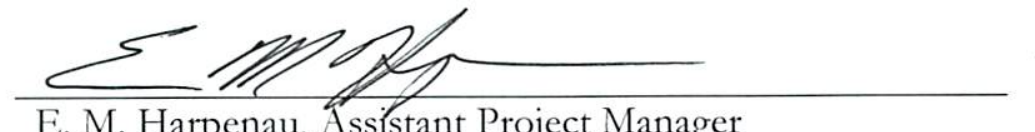

Date:

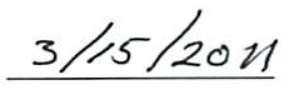

E. M. Harpenau, Assistant Project Manager

Independent Environmental Assessment and Verification

Reviewed by: Gad for

P. C. Weaver, Project Manager

Independent Environmental Assessment and Verification

Reviewed by: Erita 1 . Bavlly

E.N. Bailey, Deputy Survey Pr $\phi$ jects Manager

Date:

Date: $3 / 15 / 11$

Independent Environmental Assessment and Verification

Reviewed by:

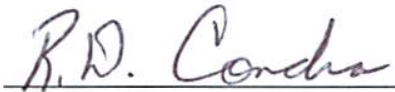

Date:

R. D. Condra, Laboratory Group Manager

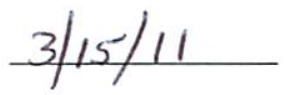

Independent Environmental Assessment and Verification

Reviewed by:

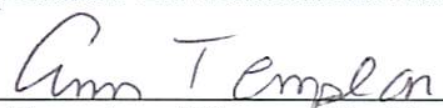

Date:

F. A. Templon, Director BusOps and QA

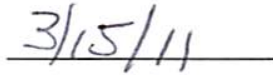

Independent Environmental Assessment and Verification 


\begin{tabular}{|c|c|}
\hline & TABLE OF CONTENTS \\
\hline 1.0 & INTRODUCTION AND SITE HISTORY \\
\hline 2.0 & SITE DESCRIPTION \\
\hline 3.0 & OBJECTIVES \\
\hline 4.0 & 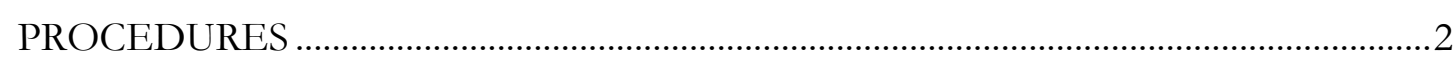 \\
\hline 4.1 & DOCUMENT REVIEW ................................ \\
\hline 4.2 & 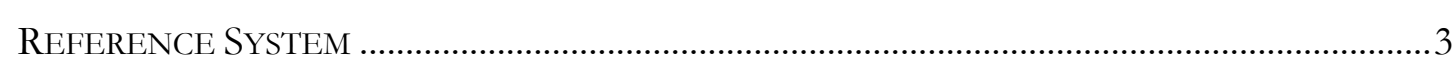 \\
\hline 4.3 & 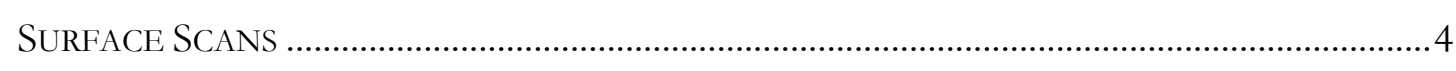 \\
\hline 4.4 & STATISTICAL SAMPLING DESIGN \\
\hline 4.5 & SOIL SAMPLING \\
\hline 4.6 & 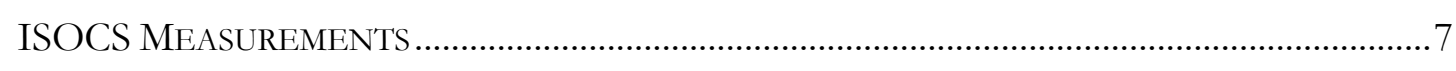 \\
\hline 5.0 & 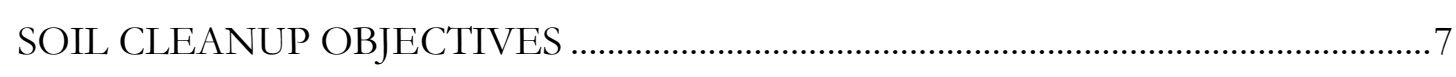 \\
\hline 6.0 & SAMPLE ANALYSIS AND DATA INTERPRETATION \\
\hline 7.0 & 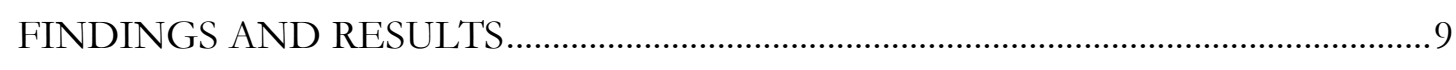 \\
\hline 7.1 & 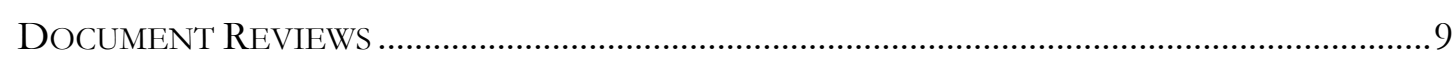 \\
\hline 7.2 & 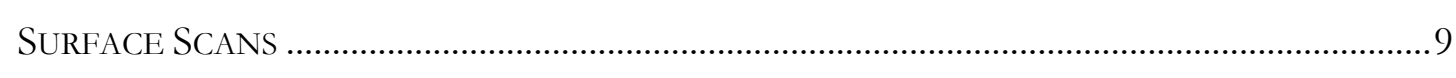 \\
\hline 7.3 & 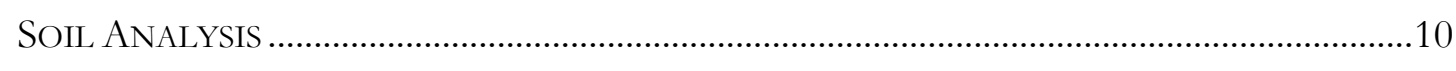 \\
\hline 8.0 & 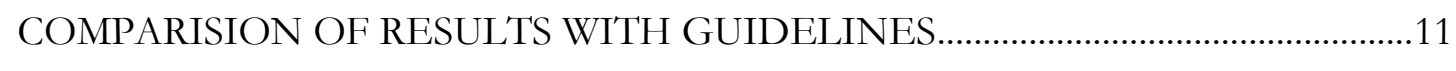 \\
\hline 9.0 & CONCLUSION \\
\hline 10.0 & REFERENCES \\
\hline \multicolumn{2}{|c|}{$\begin{array}{l}\text { APPENDIX A: FIGURES } \\
\text { APPENDIX B: TABLES } \\
\text { APPENDIX C: MAJOR INSTRUMENTATION } \\
\text { APPENDIX D: SURVEY AND ANALYTICAL PROCEDURES }\end{array}$} \\
\hline
\end{tabular}




\section{LIST OF FIGURES}

Figure A-1: Separations Process Research Unit (SPRU) at the Knolls Atomic

Power Laboratory A-1

Figure A-2: SPRU Plot Plans for the Lower Level Land Area and North

Field Project A-2

Figure A-3: SPRU Lower Level Land Area Final Status Survey Units . A-3

Figure A-4: North Field Project Final Status Survey Units A-4

Figure A-5: Lower Level Land Area Surface Scans with 2x2 Detector. A-5

Figure A-6: North Field Project Surface Scans with 2x2 Detector A-6

Figure A-7: Lower Level Land Area Surface Scans with FIDLER Detector A-7

Figure A-8: Radiological RSS Sample Locations for the Lower Level

Land Area

Figure A-9: Radiological Judgmental Sample Locations for the Lower Level

Land Area

Figure A-10: Chemical Sample Locations for the Lower Level Land Area A-10

Figure A-11: RCRA Sample Locations for the Lower Level Land Area..... A-11

Figure A-12: RCRA Sample Location Type for the Lower Level Land Area. A-12

Figure A-13: Radiological RSS Sample Locations for the North Field Project.

Figure A-14: Judgmental Radiological ISOCS Sample Locations for the North

Field Project A-14 


\section{LIST OF TABLES}

Table 1: Separations Process Research Unit Survey Unit Summary 3

Table 2: Radionuclides of Concern DCGLs Separations Process Research Unit

Niskayuna, New York. 8

Table 3: Chemical Constituents of Concern Soil Cleanup Objectives Separations Process Research Unit Niskayuna, New York. 8

Table B-1: Summarized Radionuclide Concentration Ranges in Soil by Gamma Spectroscopy Lower Level Land Area Separations Process Research Unit Niskayuna, New York .......................B-1 Table B-2: Summarized Radionuclide Concentration Ranges in Soil by Gamma Spectroscopy North Field Project Separations Process Research Unit Niskayuna, New York

Table B-3: Summarized Radionuclide Concentration Ranges in Soil by Alpha Spectroscopy

Separations Process Research Unit Niskayuna, New York

Table B-4: Summarized Radionuclide Concentration Ranges in Soil by Alpha Spectroscopy

Separations Process Research Unit Niskayuna, New York.

Table B-5: Concentrations of Chemicals in Soil Samples Separations Process Research Unit

Niskayuna, New York.

Table B-6: RCRA Samples for Chemicals in Soil Samples Separations Process Research Unit

Niskayuna, New York B-6 


\section{ABBREVIATIONS AND ACRONYMS}

\begin{tabular}{|c|c|}
\hline $\mathrm{BKG}$ & background \\
\hline $\mathrm{cm}$ & centimeter \\
\hline $\mathrm{COC}$ & constituents of concern \\
\hline cpm & counts per minute \\
\hline CSAP/FSS & Confirmation Sample Analysis Plan/Final Status Survey \\
\hline DCGL & derived concentration guideline level \\
\hline DER & Division of Environmental Remediation \\
\hline DOE & U.S. Department of Energy \\
\hline FIDLER & Field Instrument for the Detection of Low Energy Radiation \\
\hline FSS & final status survey \\
\hline GPS & Global Positioning System \\
\hline in & inch \\
\hline ISM & Integrated Safety Management \\
\hline ISOCS & In-Situ Object Counting System \\
\hline ITP & Intercomparison Testing Program \\
\hline IV & independent verification \\
\hline JHA & Job Hazard Analyses \\
\hline KAPL & Knolls Atomic Power Laboratory \\
\hline$\mu \mathrm{g} / \mathrm{kg}$ & microgram per kilogram \\
\hline $\mathrm{mg} / \mathrm{kg}$ & milligram per kilogram \\
\hline LLLA & Lower Level Land Area \\
\hline LLPL & Lower Level Parking Lot \\
\hline MAPEP & Mixed Analyte Performance Evaluation Program \\
\hline MARSSIM & Multi-Agency Survey and Site Investigation Manual \\
\hline MDC & minimum detectable concentration \\
\hline $\mathrm{NaI}$ & sodium iodide \\
\hline NFP & North Field Project \\
\hline NIST & National Institute for Standards and Technology \\
\hline NRIP & National Radiochemistry Intercomparison Program \\
\hline NYSDEC & New York State Department of Environmental Conservation \\
\hline ORAU & Oak Ridge Associated Universities \\
\hline ORISE & Oak Ridge Institute for Science and Education \\
\hline $\mathrm{pCi} / \mathrm{g}$ & picocuries per gram \\
\hline PSP & Project-Specific Plan \\
\hline QAPP & Quality Assurance Project Plan \\
\hline
\end{tabular}




\section{ABBREVIATIONS AND ACRONYMS}

$\begin{array}{ll}\text { RCRA } & \text { Resource Conservation and Recovery Act } \\ \text { ROCs } & \text { radionuclides of concern } \\ \text { RSS } & \text { ranked set sampling } \\ \text { SCOs } & \text { Soil Cleanup Objectives } \\ \text { SDSA } & \text { Slurry Drum Storage Area } \\ \text { SOF } & \text { sum of fractions } \\ \text { SPRU } & \text { Separations Process Research Unit } \\ \text { TAP } & \text { total absorption peak } \\ \text { VSP } & \text { Visual Sample Plan }\end{array}$




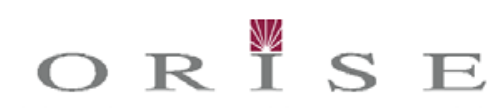

\section{INDEPENDENT VERIFICATION SURVEY ACTIVITIES AT THE SEPARATIONS PROCESS RESEARCH UNIT SITES, NISKAYUNA, NEW YORK}

\subsection{INTRODUCTION AND SITE HISTORY}

The Separations Process Research Unit (SPRU) complex located on the Knolls Atomic Power Laboratory (KAPL) site in Niskayuna, New York, was constructed in the late 1940s to research the chemical separation of plutonium and uranium (Figure A-1). SPRU operated as a laboratory scale research facility between February 1950 and October 1953. The research activities ceased following the successful development of the reduction oxidation and plutonium/uranium extraction processes. The oxidation and extraction processes were subsequently developed for large scale use by the Hanford and Savannah River sites (aRc 2008a). Decommissioning of the SPRU facilities began in October 1953 and continued through the 1990s.

The U.S. Department of Energy (DOE) used its authority under the Comprehensive Environmental Response, Compensation, and Liability Act to pursue cleanup of radioactivity and heavy metal chemicals of impacted soils in land areas utilized for SPRU operations. The objectives for this work included (1) restoring the Lower Level Land Area (LLLA) and North Field Project (NFP) area to a state suitable for reuse by KAPL in an area zoned for industrial and research use, (2) reducing surveillance and maintenance costs, and (3) reducing or eliminating the potential for future radiological and chemical releases from the SPRU land areas (aRc 2008b and 2009). After being awarded the contract, Accelerated Remediation Company began completing the last phases of decommissioning for the LLLA and NFP (Figure A-2). The contractor completed remediation of the former SPRU research operations in the LLLA and the NFP in late 2010.

The DOE Office of Environmental Management requested the services of Oak Ridge Institute for Science and Education (ORISE) to conduct independent verification (IV) of decontamination activities of specific land areas associated with the former SPRU operations. These verification activities included assessments of residual radiological contaminants in soil and in a few areas, provide verification that heavy metal chemical concentrations are within the established criteria. ORISE performed IV activities during the period of September 29, 2008 through August 25, 2010. 


\subsection{SITE DESCRIPTION}

The SPRU complex, situated along the bank of the Mohawk River, occupied approximately 15 acres in the northwest corner of the 170 acre KAPL site. The LLLA at SPRU consisted of the Lower Level Parking Lot (LLPL), the Railroad Staging Area, the former K5 Retention Basin, and the former K6 and K7 waste storage pads (aRc 2008a). These were subdivided into at least 40 final status survey (FSS) units designated as either Class 1, 2, or 3. During remediation and FSS activities, survey units were added and/or initial FSS unit boundaries were restructured (Figure A-3).

The NFP included an area of 15 acres of relatively flat field and sparsely wooded area located within the southeastern boundary of the KAPL site (Figure A-4). The NFP site was designated as the Slurry Drum Storage Area (SDSA) for staging and temporary storage of the slurry generated in the extraction process (DOE 2006). In 1955, the bermed walls of the SDSA were bulldozed into the area as fill following the completion of SPRU operations. The contractor determined seventeen FSS units were necessary based on result of previous use and excavations.

\subsection{OBJECTIVES}

The objectives of IV were to confirm that remedial actions have been effective in meeting established release criteria and that documentation accurately and adequately describes the final radiological conditions and heavy metal chemical conditions (where required) of the LLLA and NFP.

\subsection{PROCEDURES}

ORISE site verification activities were performed during the period of September 29, 2008 through August 25, 2010 in accordance with Project-Specific Plans (PSPs) submitted to and approved by DOE, the ORISE Survey Procedures Manual, and the ORAU Quality Program Manual (ORISE 2008a and 2010a, 2008b, and ORAU 2009). ORISE activities included surface scans for both low and high energy gamma emitters, In-Situ Object Counting System (ISOCS) gamma measurements, observation of gamma walkover surveys, along with systematic and judgmental soil sample collection. Verification surveys were performed for FSS survey units 1 through 11, 13, and, 14 at the LLLA and units 101 through 110 and 112 through 116 at the NFP site. Survey unit information is summarized in Table 1 and in Figures A-3 and A-4. 


\begin{tabular}{|c|c|c|c|}
\hline \multicolumn{4}{|c|}{$\begin{array}{c}\text { TABLE 1: } \\
\text { SEPARATIONS PROCESS RESEARCH UNIT SURVEY } \\
\text { UNIT SUMMARY }{ }^{\mathrm{a}}\end{array}$} \\
\hline \multicolumn{2}{|c|}{ Lower Level Land Area } & \multicolumn{2}{|c|}{ North Field Project } \\
\hline Survey Unit ID & Classification & Survey Unit ID & Classification \\
\hline FSS 1 & 1 & FSS 101 & 1 \\
\hline FSS 2 & 1 & FSS 102 & 1 \\
\hline FSS 3 & 1 & FSS 103 & 1 \\
\hline FSS 4 & 1 & FSS 104 & 1 \\
\hline FSS 5 & 1 & FSS 105 & 1 \\
\hline FSS 6 & 1 & FSS 106 & 1 \\
\hline FSS 7 & 1 & FSS 107 & 1 \\
\hline FSS 8 & 2 & FSS 108 & 1 \\
\hline FSS 9 & 1 & FSS 109 & 2 \\
\hline FSS 10 & 1 & FSS 110 & 1 \\
\hline FSS 11 & 1 & FSS 111 & 2 \\
\hline FSS 13 & 1 & FSS 112 & 1 \\
\hline FSS 14 & 1 & FSS 113 & 1 \\
\hline FSS L & 1 & FSS 114 & 2 \\
\hline FSS N & 2 & FSS 115 & 2 \\
\hline FSS N1 & 2 & FSS 116 & 2 \\
\hline FSS O & 2 & FSS 117 & 3 \\
\hline FSS P & 2 & & \\
\hline FSS S & 1 & & \\
\hline
\end{tabular}

aRefer to Figures A-3 and A-4

\subsection{Document RevieW}

ORISE reviewed the Radiological Confirmation Sampling Analysis Plans/Final Status Surveys (CSAP/FSS) (aRc 2008b and 2009), for agreement with the Multi-Agency Radiation Survey and Site Investigation Manual (MARSSIM), Resource Conservation and Recovery Act (RCRA) work plan (aRc 2008a), and associated Quality Assurance Project Plan (QAPP) documents for technical content. ORISE also reviewed FSS data as it was provided by the contractor.

Overall, project documentation set forth the necessary requirements for the contractor to complete site remediation.

\subsection{REFERENCE SYSTEM}

ORISE used a global positioning system (GPS) for documenting survey area boundaries, tracking survey data, and identifying measurement and sampling locations. Typically, boundaries for the 
specified survey areas were obtained from coordinates provided by the remediation contractor and uploaded to handheld GPS units. FSS unit boundaries would vary on occasion from original coordinates and adjustments would be made on-site. Once the survey area was bounded, GPS units were integrated with gamma radiation detectors coupled to ratemeter-scalers to collect position and gamma radiation count rate data during walkover scans. The specific geographic coordinate system required for documentation was the New York State Plane Coordinate System. GPS coordinates were typically accurate to within one meter of any given position data point.

\subsection{SURFACE SCANS}

High density scans for gamma radiation were performed in accessible areas at LLLA and the NFP sites. Scans were primarily performed using a 2-inch $\times 2$-inch $(2 \times 2)$ sodium iodide $(\mathrm{NaI})$ scintillation detector. Detectors were coupled to a ratemeter-scaler with audible output. Locations of suspect, elevated direct gamma levels were identified in real-time via the audio output. Additionally, the electronic data were plotted and reviewed to identify any anomalies. Scan results collected using $2 \times 2$ detectors for the LLLA and NFP are provided in Figures A-5 and A-6. Locations of suspect elevated direct gamma radiation were identified for further investigation, as necessary.

To gain a higher efficiency for detecting the low energy radionuclides of plutonium and americium, ORISE used the Field Instrument for the Detection of Low Energy Radiation (FIDLER) NaI scintillation detector (ORISE 2009a and b). FIDLER scans, in correlation with the surveys conducted with the $2 \times 2$ detector, were completed in several FSS units. The FIDLER scan data is illustrated in Figure A-7.

\subsection{Statistical SAMPLing Design}

Visual Sample Plan (VSP) software was used to generate random coordinates for gamma measurements and soil sampling. These measurement/sample points were down-loaded to the GPS and were based upon the reference grid system established by the site. These predetermined random field assessment and resultant soil sample locations were designed and generated based on the ranked set sampling (RSS) approach (EPA 2006). 
The statistically-based RSS design was used to determine the number of random samples that would be required to estimate that the mean concentration of the analytes of concern do not exceed the soil cleanup objectives (SCOs) for a given population and compare to the site's FSS results; however, it does not require the assumption of a normal distribution. The process combines random sampling with the use of professional judgment to select sampling locations. Professional judgment relies upon the ability to assess the relative magnitude of gamma radiation levels between randomly selected locations. In this case, the gamma count rate data collected at randomly selected locations provided the measurable field screening method that correlated with the relative concentrations of the gamma-emitting contaminants of concern. The count rate data obtained were then used to select a specific sampling location.

The RSS systematic planning process uses a replication method on a larger random population from which the locations for the resulting samples can be selected. Replication refers to the number of cycles $(r)$ for performing a set size $(m)$ of field measurement. The number of field assessment locations per cycle, is a function of the set size and is simply $m^{2}$. The number of field assessment locations will vary but is defined as $m^{2} \times r$, or for example $3^{2} \times 2=18$ for a particular survey unit. These measurements are grouped into cycle/sets and distributed in the survey area. The first set identification location is cycle 1 of set 1 at measurement location 1, designated as 1-1-1. Mapping the population of assessment locations uses color coding with a specific geometric shape to correspond to each RSS cycle.

A one-minute static gamma count rate measurement was performed at each of the assessment locations per the survey unit requirement. The data points within a given cycle were then ranked as exhibiting either the lowest, medium, or highest gamma count in a set. The ranking resulted in the number of soil samples required for each FSS unit.

Twelve randomly generated locations were created in FSS 9 and FSS 10 using VSP software in lieu of the typical RSS method with a one minute static count collected at each location. This decision, approved by ORISE management and SPRU personnel, was prompted by a significant portion of FSS 9 not being accessible due to a large excavation filled with water and multiple smaller excavations scattered throughout the FSS unit. FSS 10 had multiple excavations as well as two large fractional distillation tanks contained within its boundary (ORISE 2010b). 


\subsection{SOIL SAMPLING}

Surface soil samples ( 0 to $0.15 \mathrm{~m}$ ) were collected at the determined RSS or random assessment locations. DOE also required chemical analysis of the LLLA samples be performed due to heavy metal chemical concentrations, primarily arsenic, observed in initial sampling efforts conducted by the decommissioning contractor. The chemical samples were obtained from undisturbed soils at each of the assessment locations. Thirty-six random radiological samples were collected from FSS units 2, 4, 9, 10, 13, and 14 in the LLLA and three additional judgmental samples based on scans (Figures A-8 and A-9). Judgmental samples were obtained from the locations that exhibited the maximum gamma activity levels observed during scans (ORISE 2009b and 2010b).

Chemical samples were collected in FSS units 1, 4, 9, and 10 using the RSS approach. Six judgmental samples from FSS 1 were collected at the direction of DOE to verify the contractor's findings at specified locations. The remaining 18 samples were collected based either on process knowledge or the random/RSS sampling plan (Figure A-10). After the chemical verification samples had been collected, DOE determined that the random/RSS sampling approach for identifying heavy metal chemicals in FSS 13 and FSS 14 did not provide sufficient data to meet the criteria set in the RCRA Work Plan (aRc 2008a). Specific RCRA and the New York State Department of Environmental Conservation's (NYSDEC) Division of Environmental Remediation (DER) DER-10 guidance (NYSDEC 2002), results from aRc data, and professional judgment were used to determine chemical sample locations in FSS units 13 and 14. It was decided that a sample be collected every 60 feet along the sidewalls of the excavation 15C resulting in 13 samples (ORISE 2010b). This resulted in the collection of 13 new samples from the two FSS units, four samples obtained from FSS 14 and nine from FSS 13 (Figure A-11). Figure A-12 depicts each sample type as it corresponds to a given location and the analytical results are provided in Table B-6.

In the NFP, six FSS units were sampled. A set of six RSS samples were collected from the FSS units $103,109,113,114,115$, and 116. This resulted in 36 samples being collected for radiological analysis and no chemical sampling was requested (ORISE 2010c and 2010d). The location of samples within the NFP survey units are provided in Figure A-13. Several survey units were not selected for soil sampling because some areas had been backfilled prior to ORISE arriving on-site, process knowledge about radiological activities in specific areas was sufficient, or gamma walkover surveys did not indicate elevated radiation levels. 


\subsection{ISOCS MEASUREMENTS}

The ISOCS portable gamma spectroscopy unit was used to identify and provide real time isotopic distribution at two locations identified via surface scans of high gamma activity in FSS units 103 and 115 (ORISE 2010c). The soil samples were counted for ten minutes and the spectra reviewed for the radionuclides of concern (ROCs) listed in Table 2. The locations of the ISOCS samples are shown in Figure A-14.

\subsection{SOIL CLEANUP OBJECTIVES}

The cleanup objectives for the ROCs at the LLLA and NFP are provided in Table 2 along with the respective derived concentration guideline levels (DCGLs) for each. The most prominent ROC identified has been cesium-137. The heavy metal chemical constituents of concern (COCs) and the respective SCOs are provided in Table 3 (aRc 2008a). The site goal was to return the soil to KAPL suitable for future use. 


\begin{tabular}{|c|c|c|c|}
\hline \multicolumn{4}{|c|}{$\begin{array}{c}\text { TABLE 2: } \\
\text { RADIONUCLIDES OF CONCERN DCGLS } \\
\text { SEPARATIONS PROCESS RESEARCH UNIT } \\
\text { NISKAYUNA, NEW YORK }\end{array}$} \\
\hline ROC & DCGL (pCi/g) & ROC & DCGL (pCi/g) \\
\hline Am-241 & $5.74 \mathrm{E}+02$ & $\mathrm{Pu}-241$ & $1.91 \mathrm{E}+04$ \\
\hline Cs-137 & $3.00 \mathrm{E}+01$ & Pm-147 & $1.59 \mathrm{E}+06$ \\
\hline Co-60 & $9.78 \mathrm{E}+00$ & Sm-151 & $6.59 \mathrm{E}+06$ \\
\hline Eu-152 & $2.18 \mathrm{E}+01$ & Sr-90 & $4.65 \mathrm{E}+03$ \\
\hline Eu-154 & $2.01 \mathrm{E}+01$ & Tc-99 & $1.43 \mathrm{E}+06$ \\
\hline Eu-155 & $8.52 \mathrm{E}+02$ & Th-232 & $9.05 \mathrm{E}+00$ \\
\hline $\mathrm{H}-3$ & $1.04 \mathrm{E}+06$ & $\mathrm{U}-234$ & $1.16 \mathrm{E}+03$ \\
\hline Ni-63 & $5.10 \mathrm{E}+06$ & $\mathrm{U}-235$ & $1.88 \mathrm{E}+02$ \\
\hline Pu-238 & $7.92 \mathrm{E}+02$ & $\mathrm{U}-238$ & $8.51 \mathrm{E}+02$ \\
\hline Pu-239 & $7.14 \mathrm{E}+02$ & Zr-93 & $1.34 \mathrm{E}+06$ \\
\hline $\mathrm{Pu}-240$ & $7.15 \mathrm{E}+02$ & & \\
\hline
\end{tabular}

\begin{tabular}{|c|c|c|c|}
\hline \multicolumn{4}{|c|}{$\begin{array}{c}\text { TABLE 3: } \\
\text { CHEMICAL CONSTITUENTS OF CONCERN } \\
\text { SOIL CLEANUP OBJECTIVES } \\
\text { SEPARATIONS PROCESS RESEARCH UNIT } \\
\text { NISKAYUNA, NEW YORK }\end{array}$} \\
\hline $\mathrm{COC}$ & $\mathrm{SCO}(\mathrm{mg} / \mathrm{kg})^{\mathrm{a}}$ & $\mathrm{COC}$ & $\mathrm{SCO}(\mathrm{mg} / \mathrm{kg})^{\mathrm{a}}$ \\
\hline Antimony & $1^{\mathrm{b}}$ & Lead & 400 \\
\hline Arsenic & 16 & Mercury & 0.73 \\
\hline Cadmium & 2.5 & Silver & 8.3 \\
\hline Trivalent Chromium & 36 & Thallium & $2^{\mathrm{b}}$ \\
\hline Cobalt & $30^{c}$ & Vanadium & $150^{\mathrm{c}}$ \\
\hline Copper & 270 & Zinc & 2200 \\
\hline
\end{tabular}

${ }^{a} \mathrm{mg} / \mathrm{kg}=$ milligrams per kilogram.

bReporting Limit for ALS Laboratory Group.

'TAGM 4046 recommended cleanup levels (aRc 2008a). 


\subsection{SAMPLE ANALYSIS AND DATA INTERPRETATION}

Soil samples were returned to the ORISE laboratory in Oak Ridge, TN for radiological analysis and interpretation. Sample analyses were performed in accordance with the ORISE Laboratory Procedures Manual (ORISE 2010e). Soil samples were analyzed by gamma spectroscopy and alpha spectroscopy. The dominant ROC identified was cesium-137; however, gamma spectra were reviewed for any other gamma-emitting radionuclides. Alpha spectroscopy was also performed to provide supporting data to ensure the listed alpha emitting ROCs were below their respective DCGL. Spectroscopy results are reported in units of picocuries per gram (pCi/g). Analytical results were compared to the DCGLs provided in Table 2 (aRc 2008a).

Samples collected to determine chemical (specifically the heavy metal: arsenic) concentrations were analyzed by ALS Laboratory Group in Fort Collins, Colorado, a DOE Oak Ridge Operations SMO approved facility. ALS performed analyses in accordance with EPA-approved Solid Waste-846 methods 6010 and 7471 (EPA 2007). The results were reported in units of micrograms per kilogram $(\mu \mathrm{g} / \mathrm{kg})$ and converted to units of milligrams per kilogram $(\mathrm{mg} / \mathrm{kg})$.

Radiological and chemical data were compared with either the approved site DCGLs or the SCOs, as appropriate, that are provided in Tables 2 and 3 (aRc 2008a).

\subsection{FINDINGS AND RESULTS}

The results of the verification surveys for FSS units 1 through 11, 13, and 14 at the SPRU LLLA project site, and units 101 through 110 and 112 through 116 at the NFP are provided below.

\subsection{DOCUMENT REVIEWS}

Several inconsistencies were noticed within co-related documents pertaining to clean up goals, contaminants of concern, sample confirmation, and implementation of the Data Quality Objective process (ORISE 2008c and d). These issues were appropriately addressed by the contractor through implementing revised plans and work processes.

\subsection{SURFACE SCANS}

ORISE performed high density scans of all accessible areas for the FSS units covered by the independent verification activities with the exception of FSS unit 7 and FSS unit 11. Initial 
assessments of FSS unit 7 determined that the unit was not expected to contain residual contamination levels approaching the DCGLs, and therefore, received a low density scan. A significant portion of FSS 11 consisted of a steep hillside that was not easily accessible, and was also expected to have a low potential for contamination. As a result, a medium density scan of accessible areas was performed.

Additionally, ORISE was requested by the DOE to observe contractor personnel performing gamma walkover surveys. The overall walking speed of the surveyor was appropriate and the distance between the detector and ground was satisfactory. The observed surveyor kept the face of the detector pointed toward the ground during most of the swing and was not observed swinging the detector too high. However, it was noticed that the observed surveyor was not wearing headphones. Headphones should be worn while scanning in order to make it easier to detect a change in the audio output from the detector. Overall, the observed surveyor adequately performed gamma walkover surveys (ORISE 2009b).

The typical ambient background radiation levels observed with the $\mathrm{NaI}$ detectors ranged from 4,000 to $14,000 \mathrm{cpm}$. The a priori scan minimum detectable concentration (MDC) for a $2 \mathrm{x} 2$ detector is approximately $6.4 \mathrm{pCi} / \mathrm{g}$ for cesium-137 (estimated from Table 6.4 of NUREG-1507) which is less than the site specific DCGL of $30 \mathrm{pCi} / \mathrm{g}$ (NRC 1997). The areas identified as exhibiting elevated activity when compared to the rest of the FSS unit received additional investigative scans.

\subsection{SOIL ANALYSIS}

Gamma spectroscopy sample results for the independently verified FSS units are provided in Tables B-1 and B-2. Concentrations of the dominant ROC: cesium-137, ranged from -0.02 to $3.95 \mathrm{pCi} / \mathrm{g}$. Alpha spectroscopy results for americium-241; plutonium-238, 239, and 240; uranium-234, 235, and 238 are reported in Tables B-3 and B-4. The two judgmental locations sampled and analyzed using the ISOCS detector, showed no ROCs above detectable levels. The radionuclide sum-of-fractions (SOF) for each sample location was evaluated and determined to be below the threshold of 1.0 .

Analytical results for heavy metal chemicals in soil and the DOE requested RCRA samples are provided in Tables B-5 and B-6. The soil in six FSS units from the LLLA were sampled and analyzed for chemical content. The primary constituent of concern for chemicals was determined to 
be the heavy metal: arsenic. Arsenic concentrations ranged from 4 to $170 \mathrm{mg} / \mathrm{kg}$ with six sample locations in excess of the SCO. Those locations were remediated after the IV results were sent to the SPRU site.

\subsection{COMPARISION OF RESULTS WITH GUIDELINES}

The final concentrations for the analytes of concern at SPRU's LLLA and NFP meet the cleanup objectives as described in the revised CSAP. Radiological sample concentrations were less than 14\% of the respective DCGL values for all radionuclides of concern.

Chemical concentration values in excess of the SCO for arsenic were identified in FSS units 1, 9, 10, and 14 during IV sampling activities (Tables B-5 and B-6). The sample locations that exceeded the SCOs were remediated by the site contractor and the post remediation sample results were submitted to the NYSDEC, Region 4. The NYSDEC issued approval statements after evaluating the sample results for FSS units 9 and 10 (NYSDEC 2009 and 2010).

\subsection{CONCLUSION}

During the period of September 29, 2008 through August 25, 2010, ORISE conducted verification survey activities including scans, sampling, and the observation of scan surveys of the Lower Level Parking Area and North Field Project at the SPRU site. Based on the scan and sample results of the ORISE verification survey activities and approval of additional remediation activities at the SPRU site, all independently verified FSS units meet the applicable derived concentration guideline level or site cleanup objectives for radiological and chemical contaminants. 


\subsection{REFERENCES}

Accelerated Remediation Company (aRc). RCRA Interim Corrective Measures Work Plan for the Separations Process Research Unit Lower Level Land Areas Remediation. ARC-PLN-6106 Revision 4, Latham, New York; June 23, 2008 a.

Accelerated Remediation Company. Radiological Confirmation Sampling and Analysis Plan/Final Status Survey (CSAP/FSS) for the Separations Process Research Unit Lower Level Land Areas. ARC-PLN-6511 Revision 2, Latham, New York; June 16, $2008 \mathrm{~b}$.

Accelerated Remediation Company. Radiological Confirmation Sampling and Analysis Plan/Final Status Survey for the North Field Land Area. ARC-PLN-6516 Revision 0, Latham, New York; November 12, 2009.

Oak Ridge Associated Universities (ORAU). Quality Program Manual for the Independent Environmental Assessment and Verification Program. Oak Ridge, Tennessee; June 30, 2009.

Oak Ridge Institute for Science and Education (ORISE). Project-Specific Plan for Conducting InProcess Reviews and Independent Verification Surveys of the Lower Level Land Areas at the Separations Process Research Unit Niskayuna, New York. Oak Ridge, Tennessee; September 19, 2008a.

Oak Ridge Institute for Science and Education. Survey Procedures Manual for the Independent Environmental Assessment and Verification Program. Oak Ridge, Tennessee; May 1, 2008b.

Oak Ridge Institute for Science and Education. Document Review_Comments On The RCRA Interim Corrective Measures Work Plan For The Separations Process Research Unit Lower Level Land Areas Remediation And Associated Quality Assurance Project Plan, DCN: 0496-DR-01-0 August 25, 2008c.

Oak Ridge Institute for Science and Education. Document Review-Comments On The Radiological Sampling And Analysis Plan And Associated Quality Assurance Project Plan For The Separation Process Research Unit Lower Level Land Areas, Niskayuna, New York, DCN: 0496-DR-02-0 August 26, 2008d.

Oak Ridge Institute for Science and Education. Interim Report, Revision 1 - Verification Survey Activities in Final Status Survey Units 1 and 2 at the Separations Process Research Unit, Niskayuna, New York. Oak Ridge, Tennessee; May 20, 2009a.

Oak Ridge Institute for Science and Education. Draft Report - Verification Survey Activities in Final Status Survey Units 3, 4, 5, and 6 at the Separations Process Research Unit, Niskayuna, New York. Oak Ridge, Tennessee; October 21, 2009b.

Oak Ridge Institute for Science and Education. Project-Specific Plan for Conducting In-Process Reviews and Independent Verification Surveys of the North Field at the Separations Process Research Unit Niskayuna, New York. Oak Ridge, Tennessee; March 11, 2010a. 
Oak Ridge Institute for Science and Education. Final Interim Report - Verification Survey Activities in Final Status Survey Units 7, 8, 9, 10, 11, 13, and 14 at the Separations Process Research Unit, Niskayuna, New York. Oak Ridge, Tennessee; May 26, $2010 \mathrm{~b}$.

Oak Ridge Institute for Science and Education. Interim Report - Verification Survey Activities in Final Status Survey Units 101-106 and 115 at the Separations Process Research Unit North Field, Niskayuna, New York. Oak Ridge, Tennessee; July 19, 2010c.

Oak Ridge Institute for Science and Education. Interim Report - Verification Survey Activities in Final Status Survey Units 107-110, 112, 113, 114, and 116 at the Separations Process Research Unit, Niskayuna, New York. Oak Ridge, Tennessee; October 28, 2010d.

Oak Ridge Institute for Science and Education. Laboratory Procedures Manual for the Independent Environmental Assessment and Verification Program. Oak Ridge, Tennessee; March, 2010e.

New York State Department of Environmental Conservation (NYSDEC). Division of Environmental Remediation (DER). DER-10 Technical Guidance for Site Investigation and Remediation. Albany, New York; 2002.

New York State Department of Environmental Conservation. Office of Environmental Quality, Region 4. "Re: Interim RCRA ICM Data Report for Final Status Survey Unit 09, ARC-RPT-6019, Revision 0, dated 10/30/09, submitted 11/23/09." Schenectady, New York; December 16, 2009.

New York State Department of Environmental Conservation. Office of Environmental Quality, Region 4. "Re: Interim RCRA ICM Data Report for Final Status Survey Unit 10, ARC-RPT-6020, Revision 3, dated 7/28/10, submitted 7/30/10." Schenectady, New York; September 8, 2010.

U.S. Nuclear Regulatory Commission (NRC). Minimum Detectable Concentrations with Typical Radiation Survey Instruments for Various Contaminants and Field Conditions NUREG/CR-1507. Washington D.C.; 1997.

U.S. Department of Energy (DOE). Land Area Historical Site Assessment for the Separations Process Research Unit Disposition Project. Environmental Resource Group, LLC. December, 2006.

U.S. Environmental Protection Agency (EPA). Data Quality Assessment: Statistical Methods for Practitioners. EPA QA/G-9S; Washington, D.C.; February 2006.

U.S. Environmental Protection Agency. Test Methods for Evaluating Solid Waste, Physical/Chemical Methods, $3^{\text {rd }}$ Edition, Revision 6. Washington D.C.; February 2007. 


\section{APPENDIX A FIGURES}




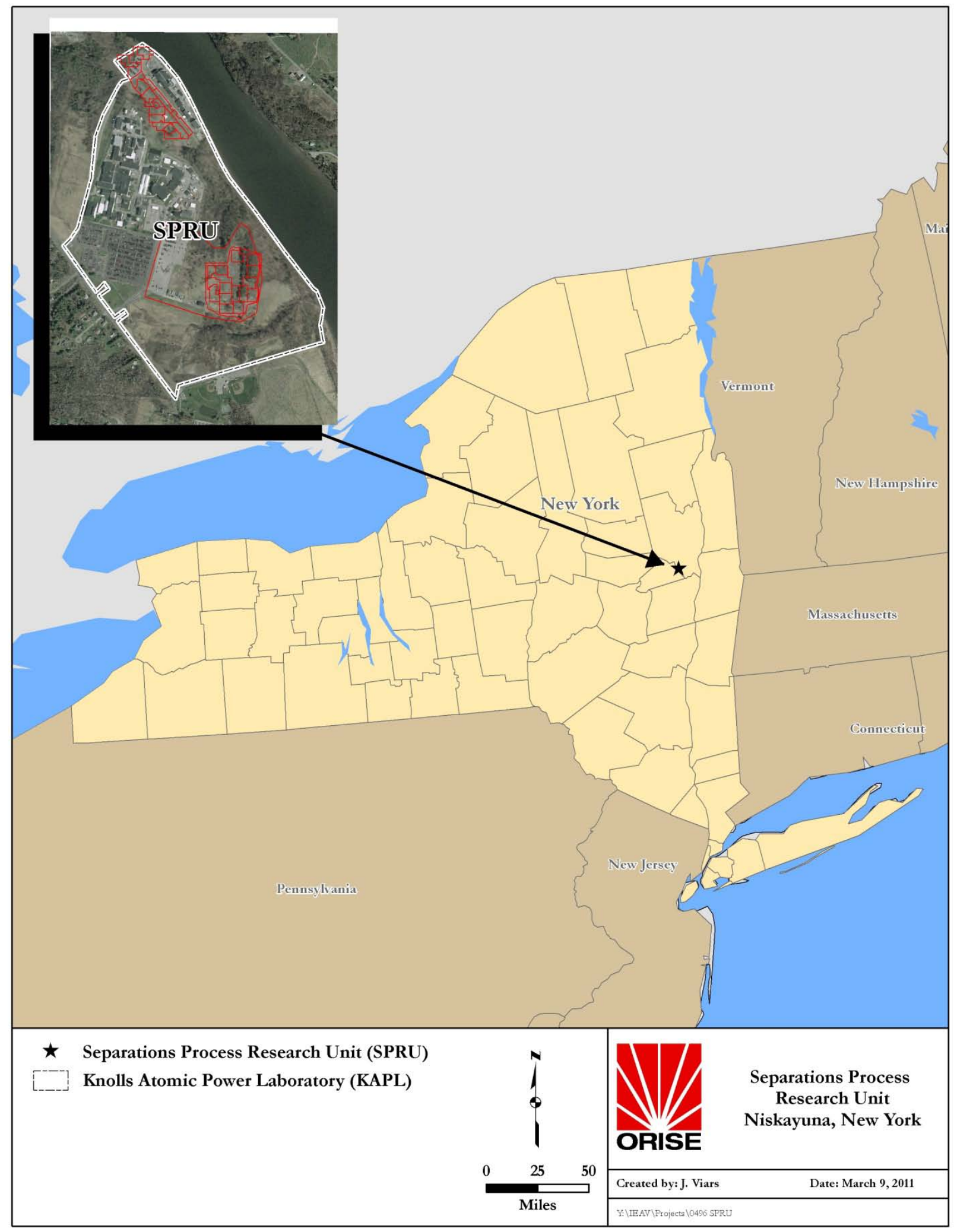

Figure A-1: Separations Process Research Unit (SPRU) at the Knolls Atomic Power Laboratory 


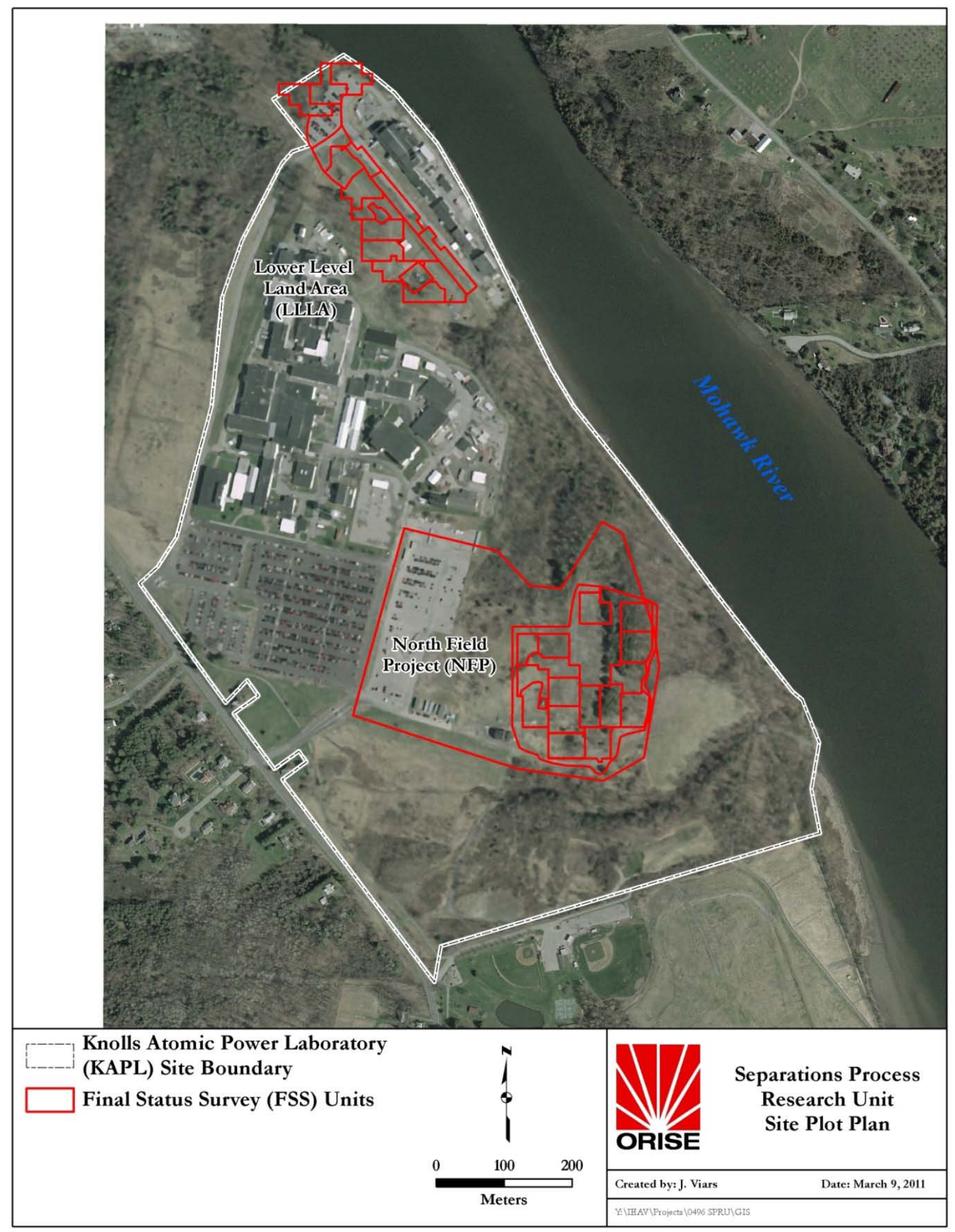

Figure A-2: SPRU Plot Plans for the Lower Level Land Area and North Field Project 


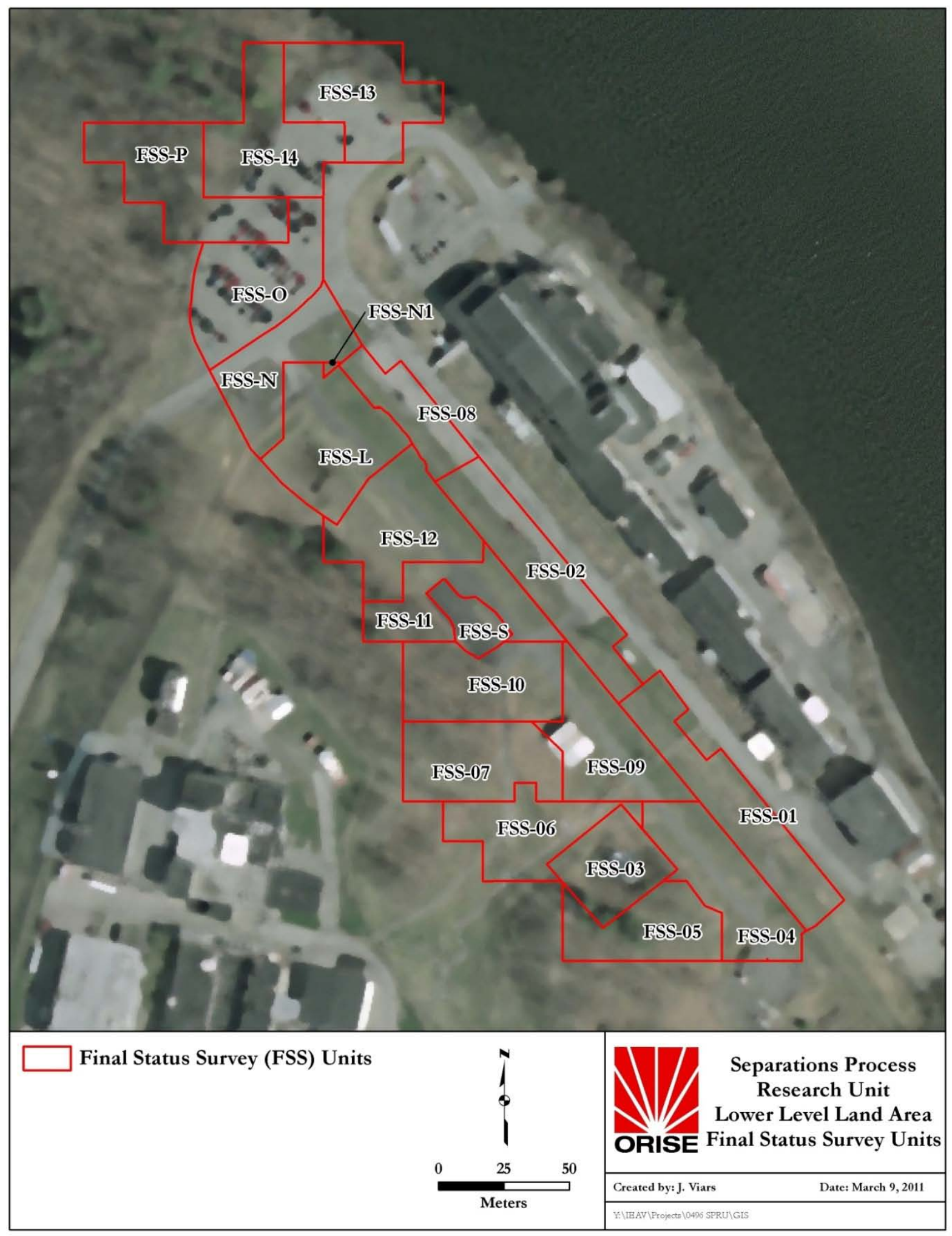

Figure A-3: SPRU Lower Level Land Area Final Status Survey Units 


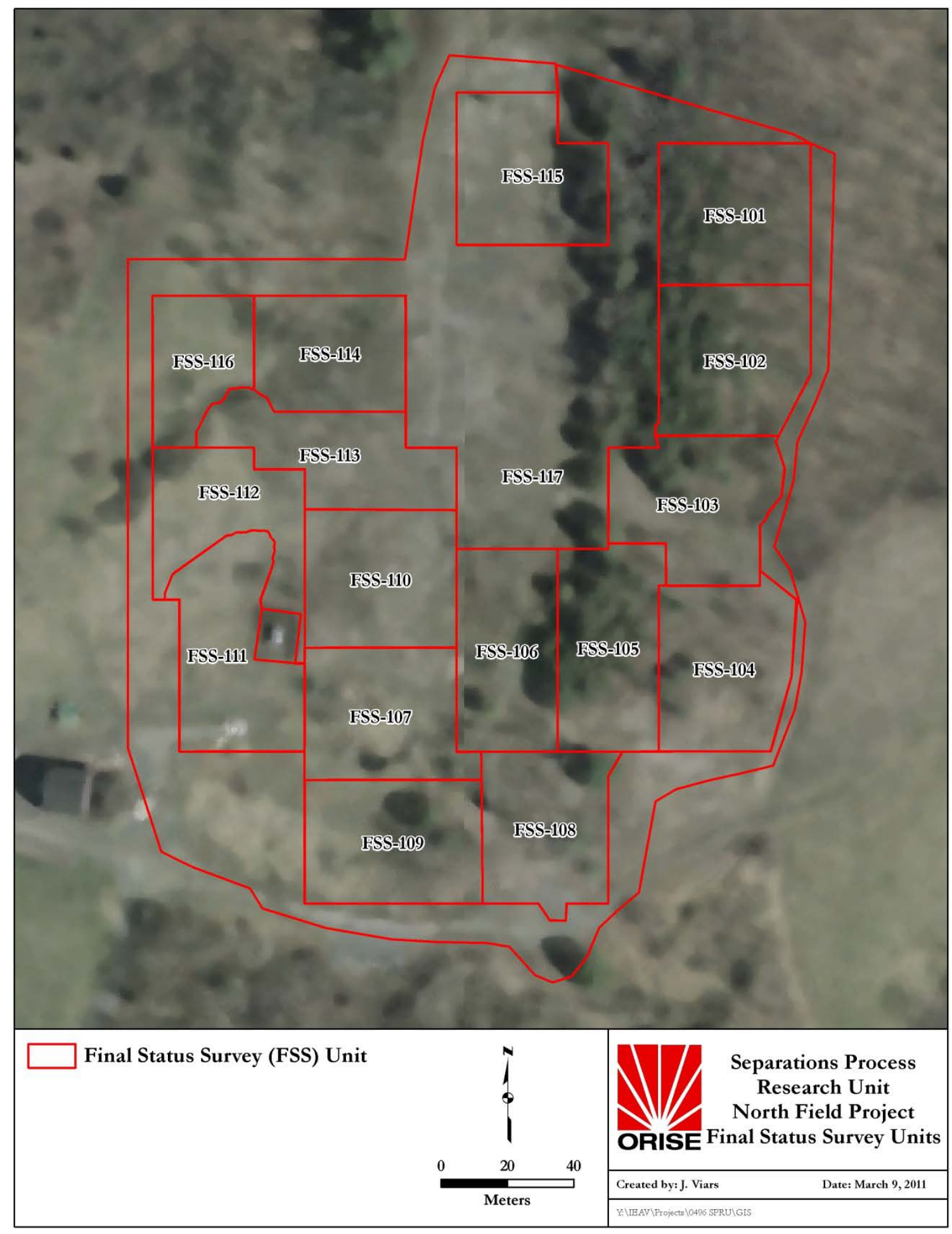

Figure A-4: North Field Project Final Status Survey Units 


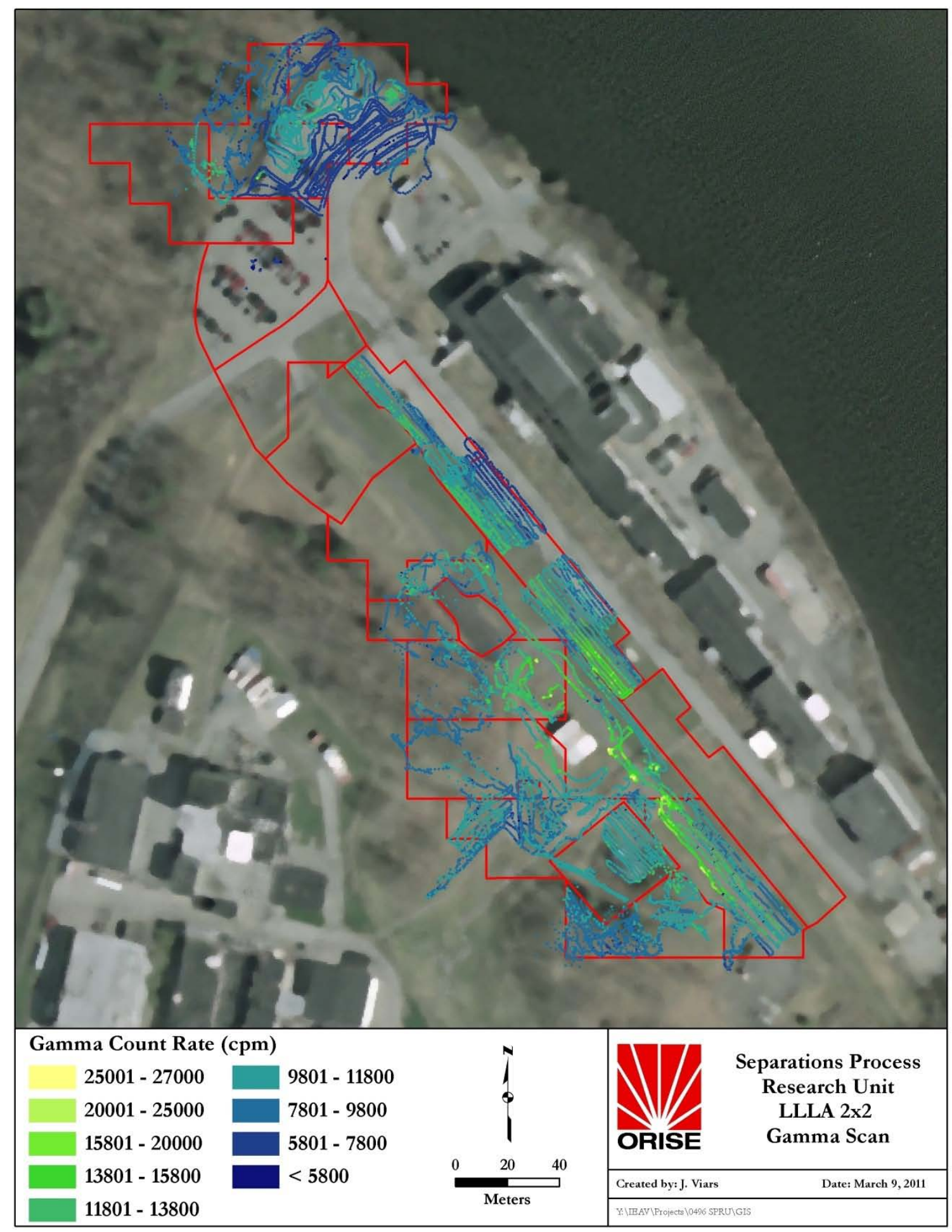

Figure A-5: Lower Level Land Area Surface Scans with 2x2 Detector 


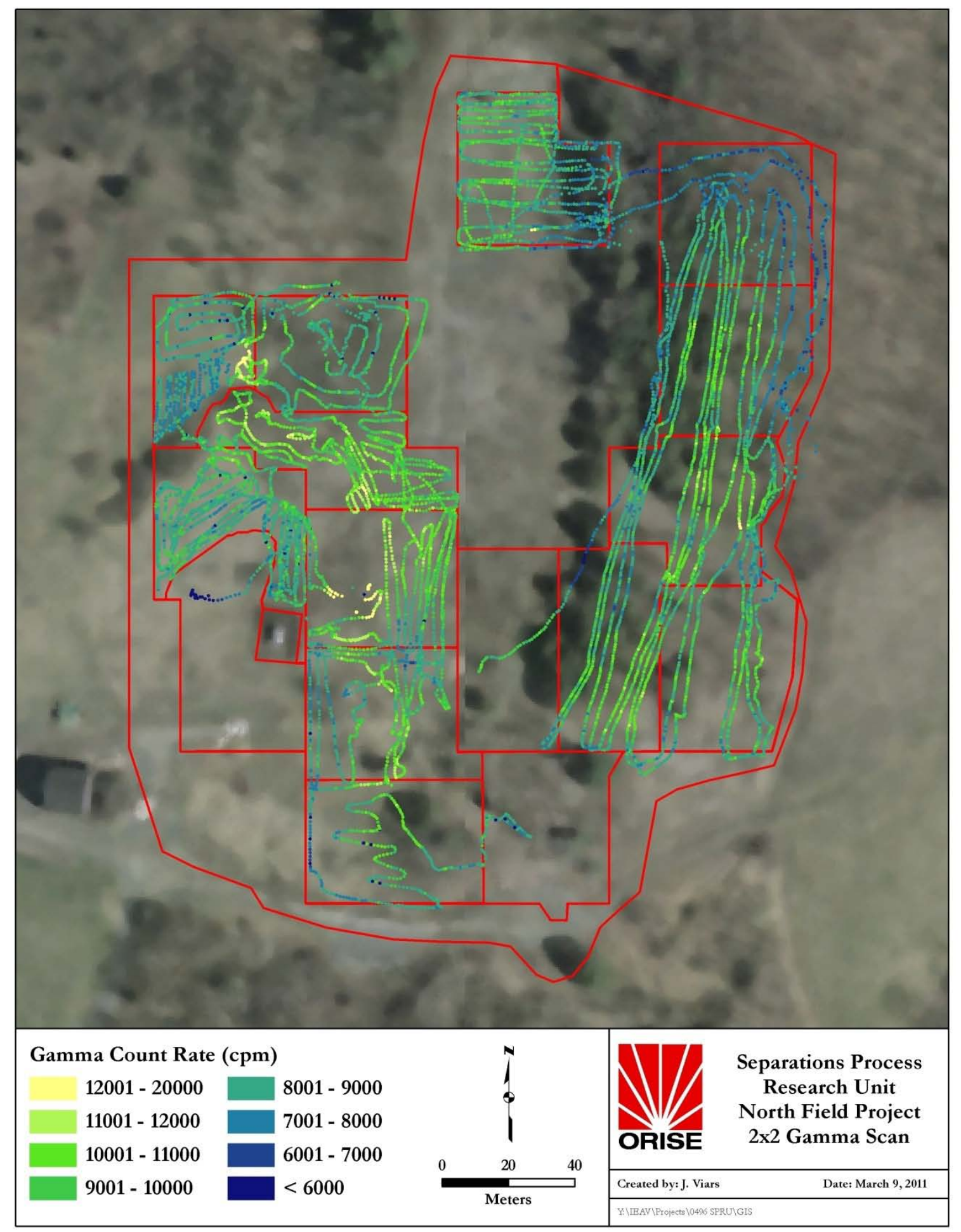

Figure A-6: North Field Project Surface Scans with 2x2 Detector 


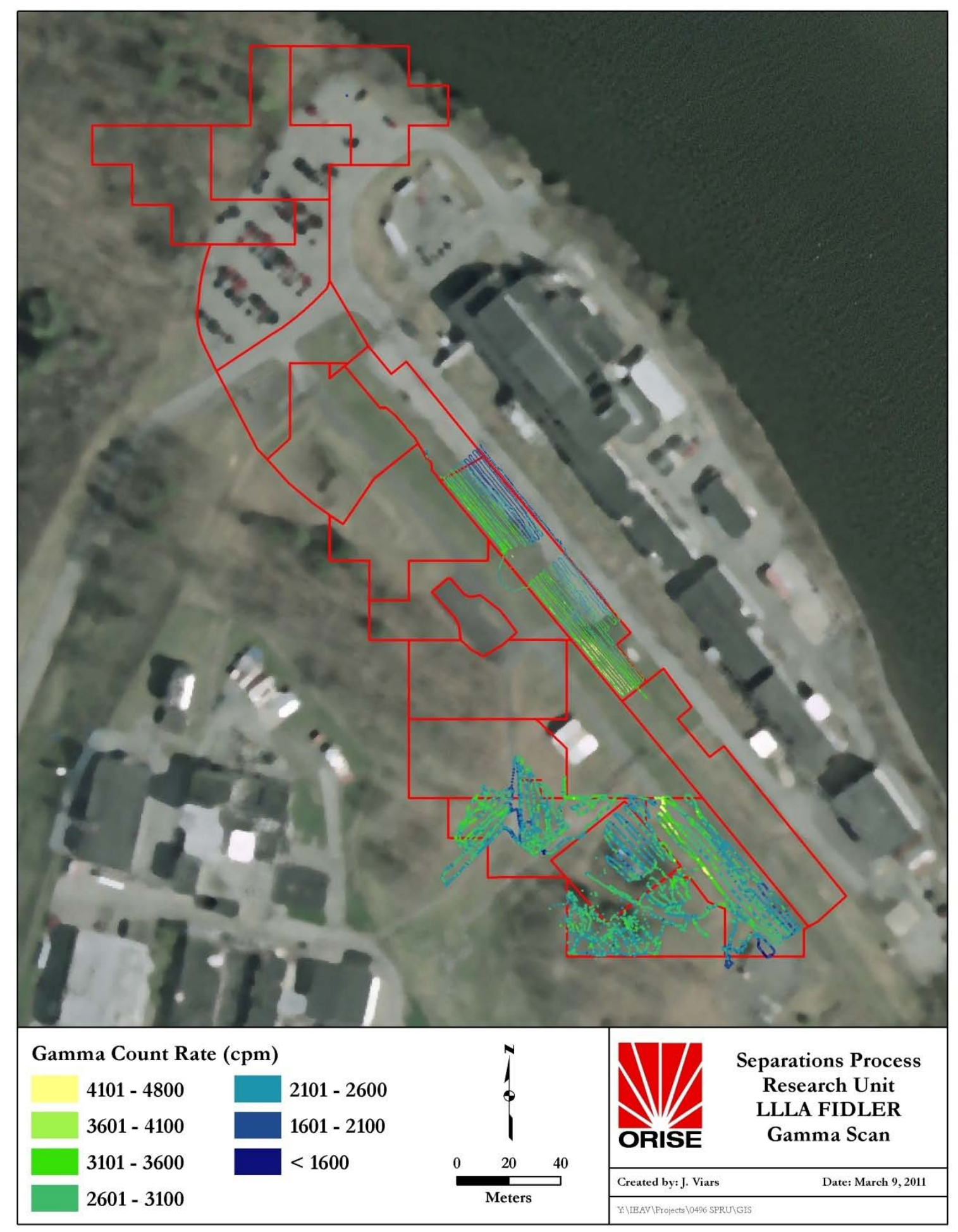

Figure A-7: Lower Level Land Area Surface Scans with FIDLER Detector 


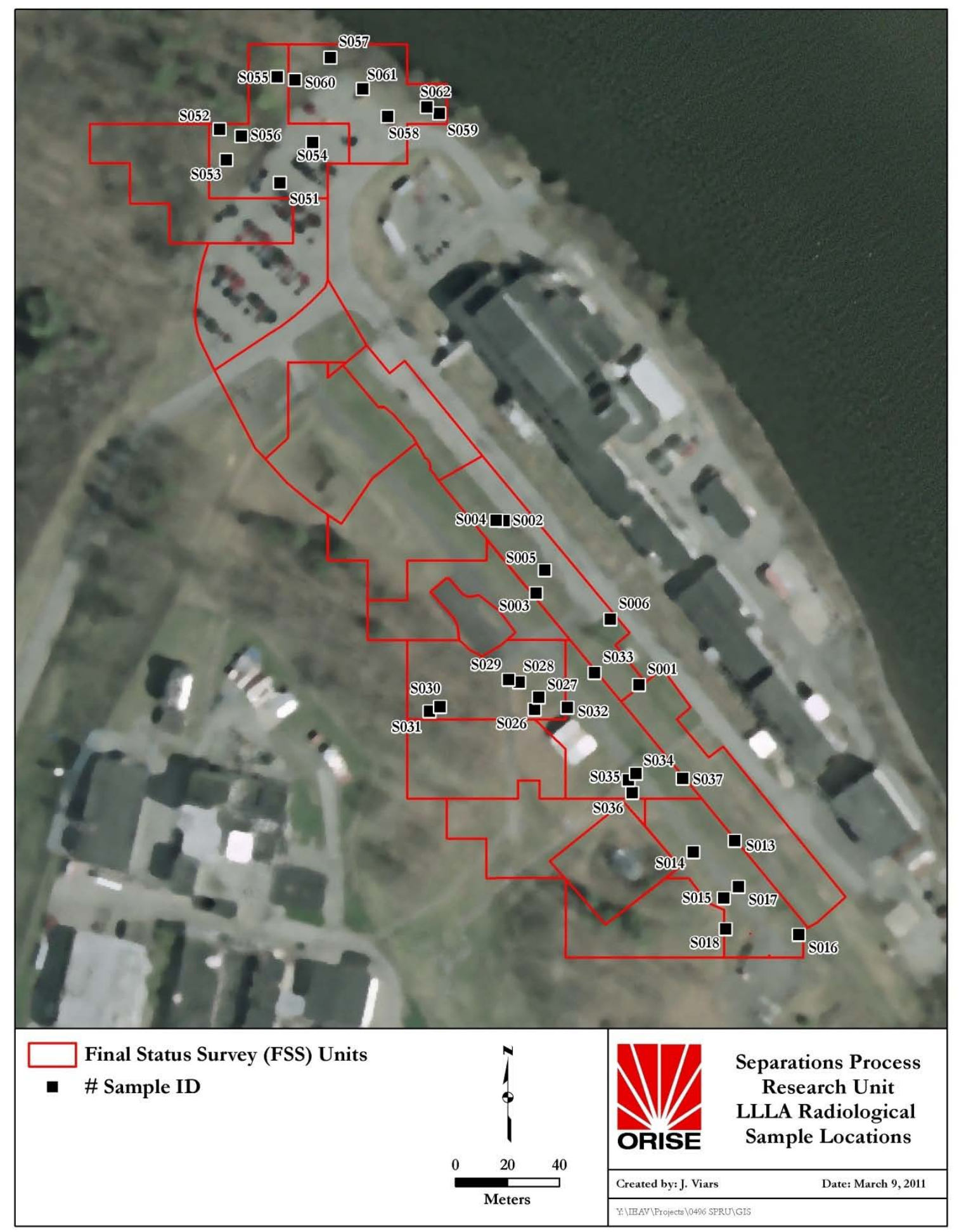

Figure A-8: Radiological RSS Sample Locations for the Lower Level Land Area 


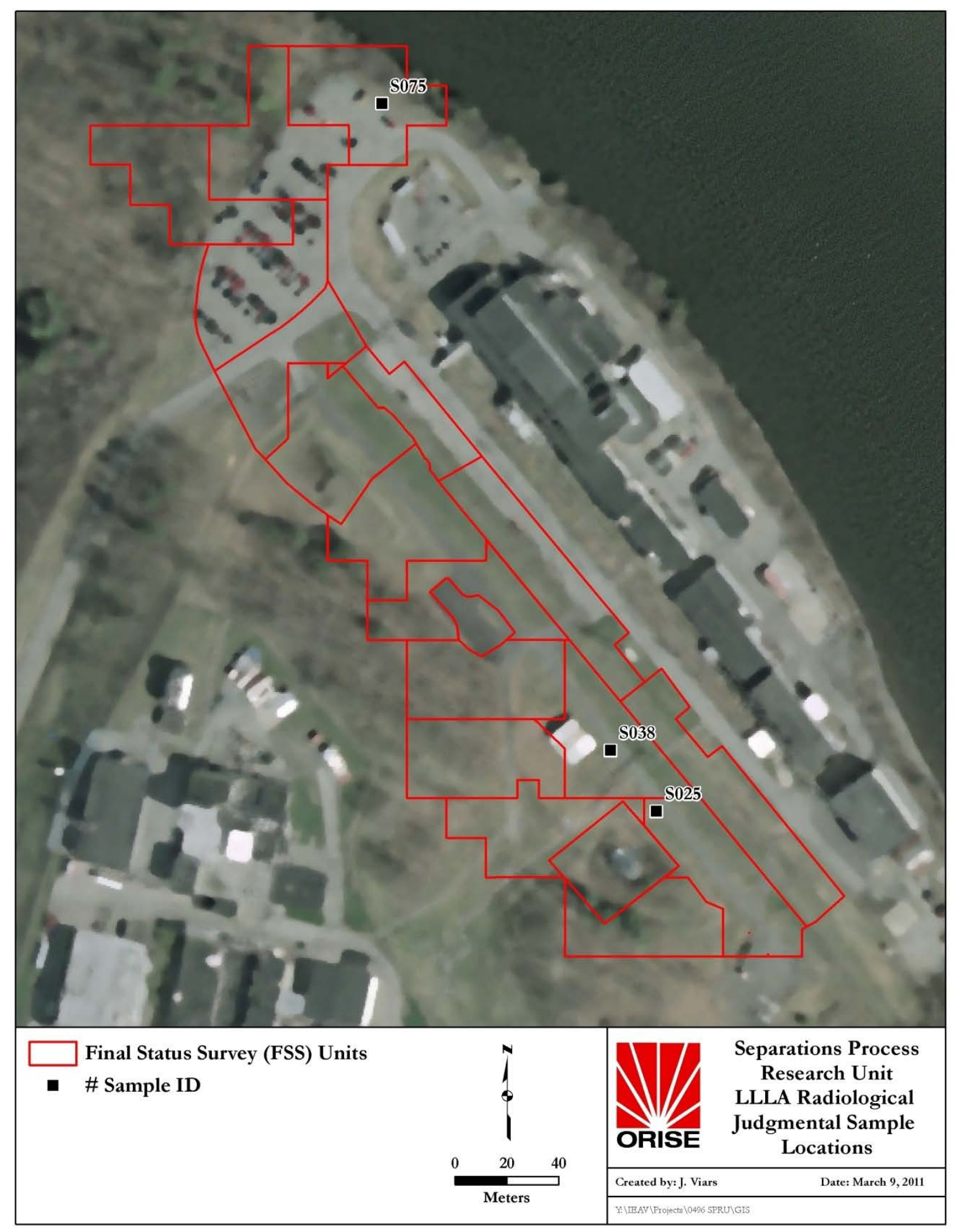

Figure A-9: Radiological Judgmental Sample Locations for the Lower Level Land Area 


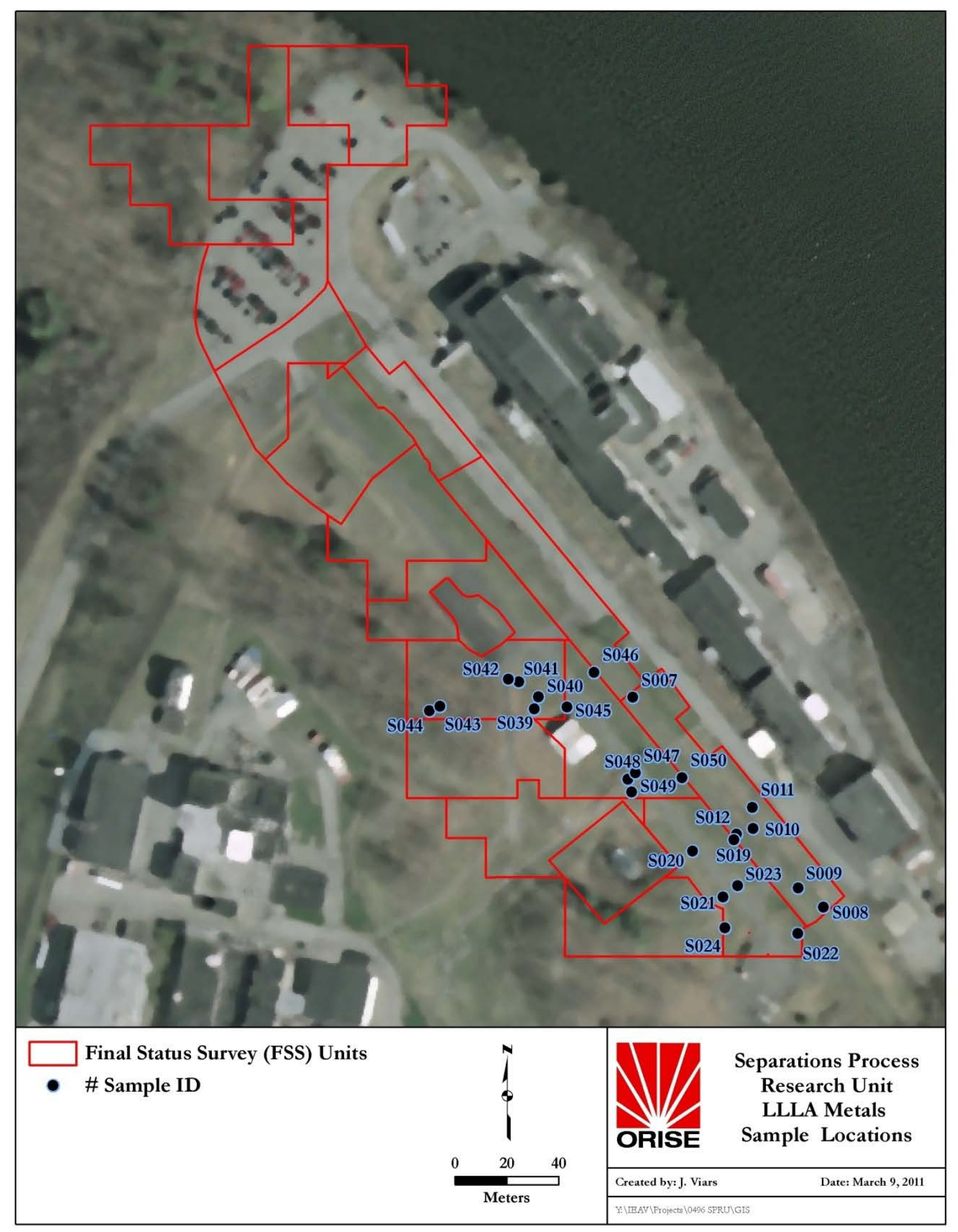

Figure A-10: Chemical Sample Locations for the Lower Level Land Area 


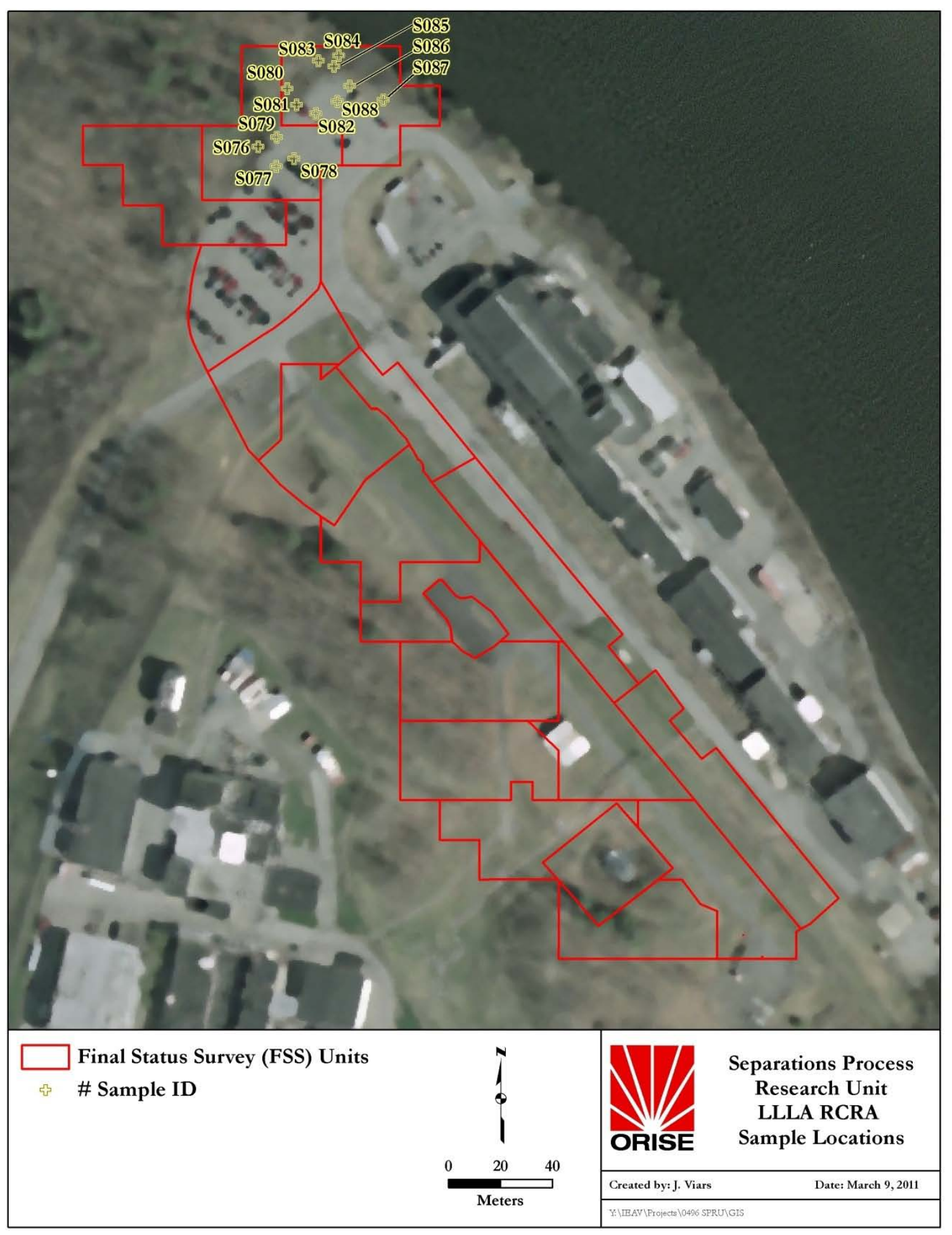

Figure A-11: RCRA Sample Locations for the Lower Level Land Area 


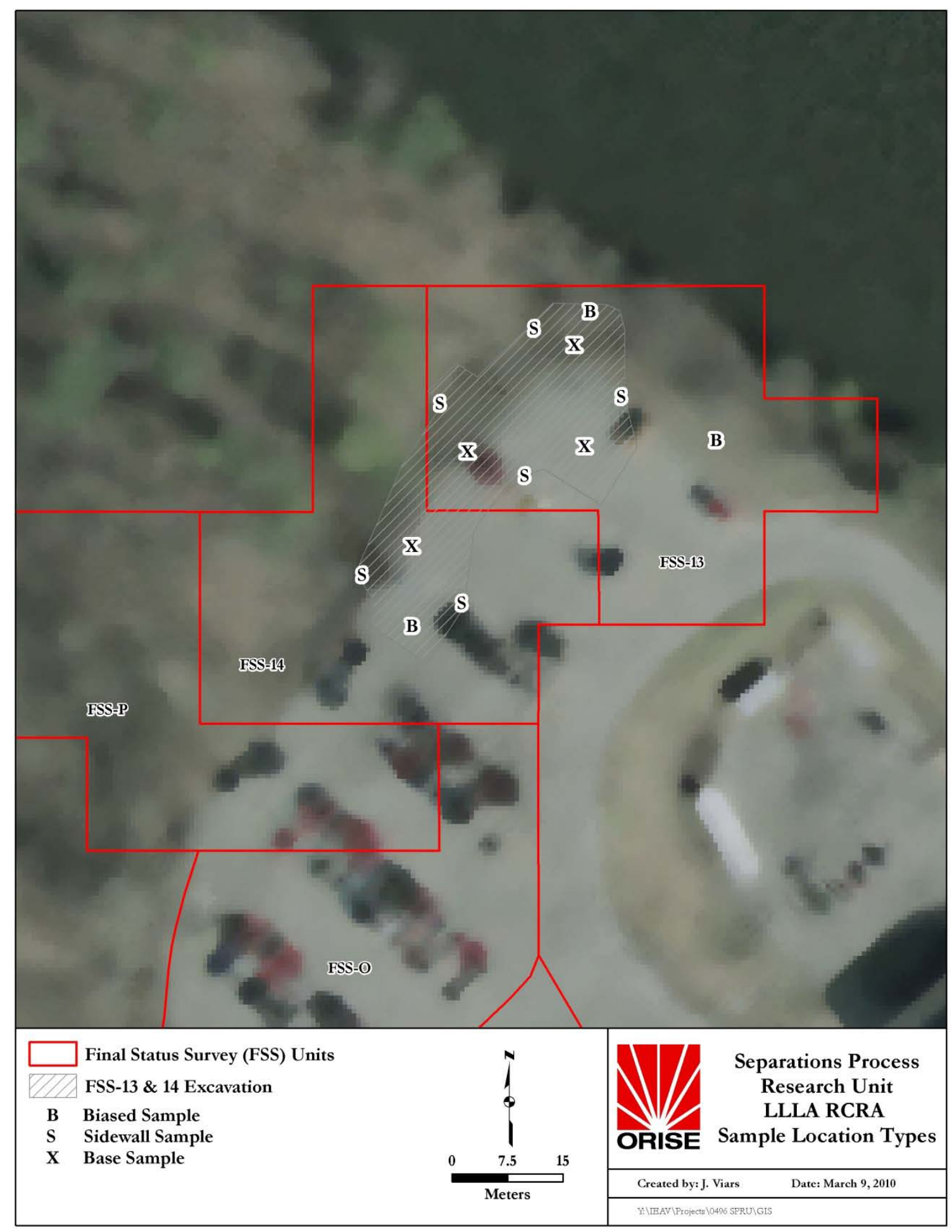

Figure A-12: RCRA Sample Location Type for the Lower Level Land Area 


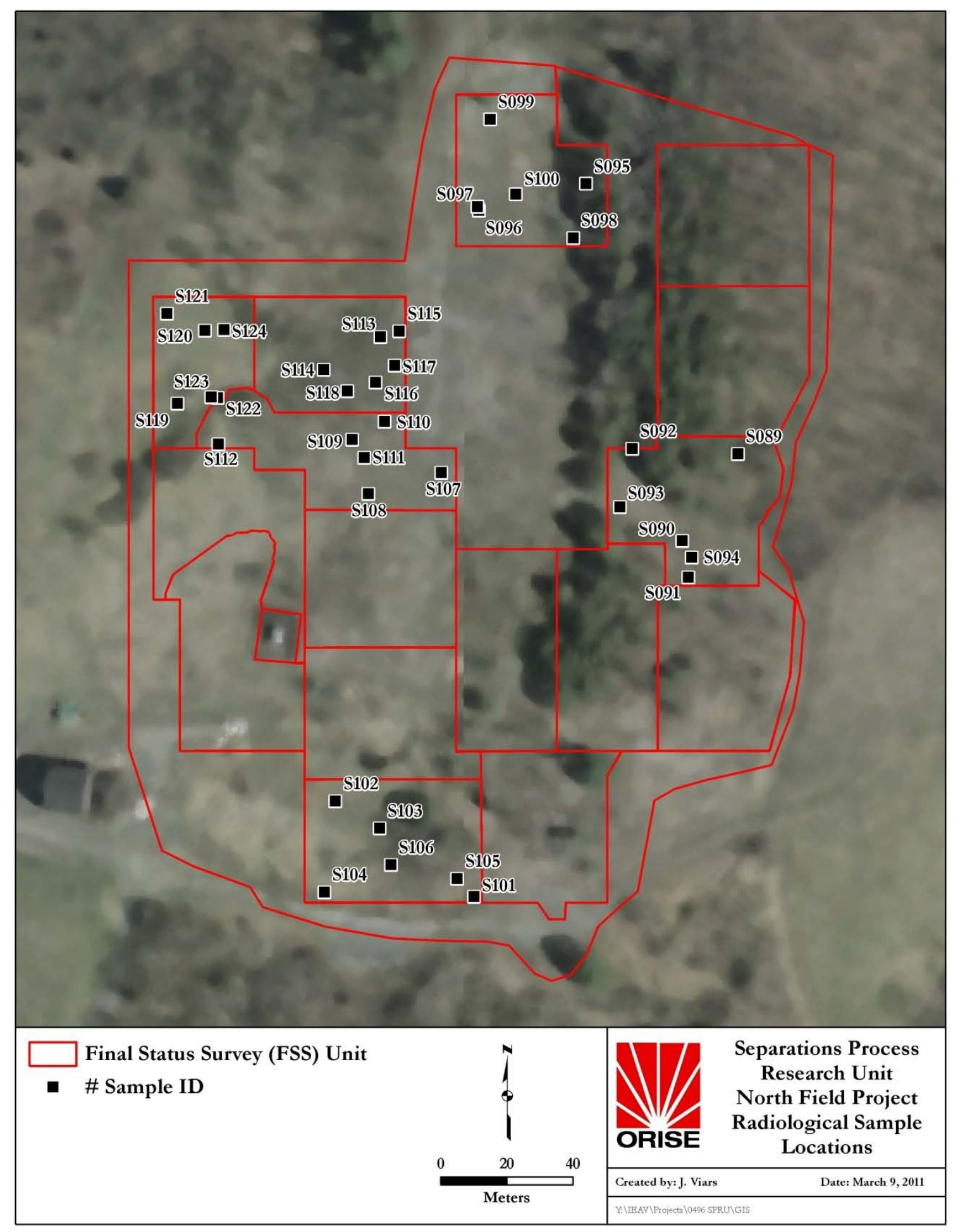

Figure A-13: Radiological RSS Sample Locations for the North Field Project 


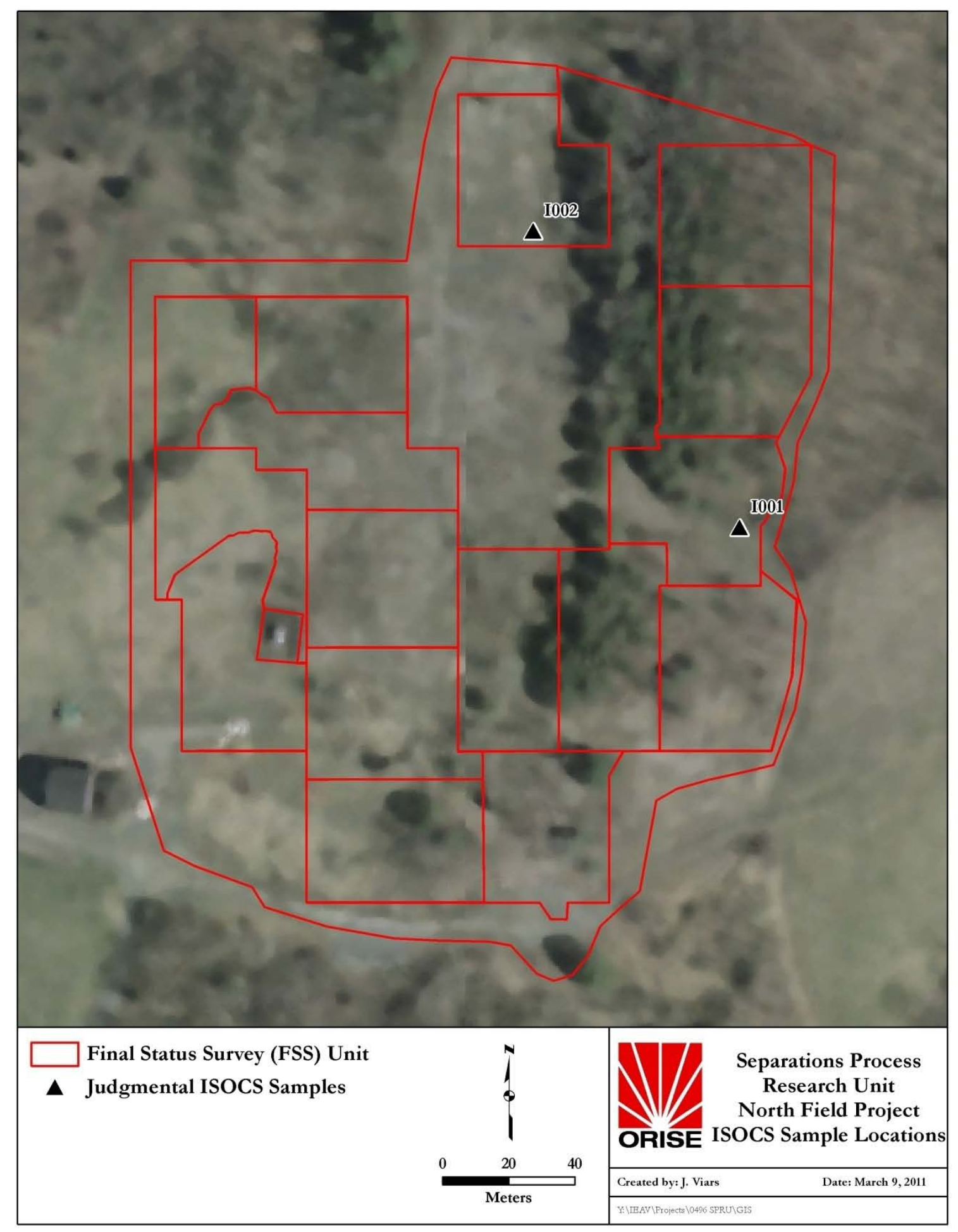

Figure A-14: Judgmental Radiological ISOCS Sample Locations for the North Field Project 


\section{APPENDIX B}

\section{TABLES}




\begin{tabular}{|c|c|c|c|c|c|}
\hline \multicolumn{6}{|c|}{$\begin{array}{c}\text { TABLE B-1: } \\
\text { SUMMARIZED RADIONUCLIDE CONCENTRATION } \\
\text { RANGES IN SOIL BY GAMMA SPECTROSCOPY } \\
\text { LOWER LEVEL LAND AREA } \\
\text { SEPARATIONS PROCESS RESEARCH UNIT } \\
\text { NISKAYUNA, NEW YORK }\end{array}$} \\
\hline \multirow{2}{*}{$\begin{array}{l}\text { Sample } \\
\text { Area }^{a}\end{array}$} & \multicolumn{5}{|c|}{ Radionuclide Concentration in Soil Samples (pCi/g) } \\
\hline & Co-60 & Cs-137 & Eu-152 & Eu-154 & Eu-155 \\
\hline \multicolumn{6}{|c|}{ Lower Level Parking Lot } \\
\hline FSS 2 & -0.02 to 0.01 & 0.06 to 0.96 & -0.90 to 0.06 & -0.41 to 0.30 & -0.03 to 0.10 \\
\hline FSS 4 & -0.04 to 0.04 & 0.25 to 3.83 & 0.01 to 0.10 & -0.03 to 0.03 & -0.01 to 0.14 \\
\hline FSS 9 & -0.03 to 0.00 & 0.08 to 3.95 & -0.07 to 0.05 & -0.03 to 0.03 & -0.06 to 0.23 \\
\hline FSS 10 & -0.04 to 0.05 & 0.20 to 0.38 & -0.06 to 0.05 & -0.02 to 0.01 & 0.02 to 0.08 \\
\hline FSS 13 & -0.03 to 0.05 & 0.04 to 0.97 & -0.05 to 0.00 & -0.06 to 0.03 & 0.02 to 0.12 \\
\hline FSS 14 & -0.03 to 0.03 & 0.03 to 0.35 & -0.02 to 0.01 & -0.02 to 0.02 & -0.04 to 0.06 \\
\hline
\end{tabular}

aRefer to Figures A-8 and A-9

\begin{tabular}{|c|c|c|c|c|c|}
\hline \multicolumn{6}{|c|}{$\begin{array}{c}\text { TABLE B-2: } \\
\text { SUMMARIZED RADIONUCLIDE CONCENTRATION } \\
\text { RANGES IN SOIL BY GAMMA SPECTROSCOPY } \\
\text { NORTH FIELD PROJECT } \\
\text { SEPARATIONS PROCESS RESEARCH UNIT } \\
\text { NISKAYUNA, NEW YORK }\end{array}$} \\
\hline \multirow{2}{*}{$\begin{array}{l}\text { Sample } \\
\text { Area }^{\mathrm{a}}\end{array}$} & \multicolumn{5}{|c|}{ Radionuclide Concentration in Soil Samples (pCi/g) } \\
\hline & Co-60 & Cs-137 & Eu-152 & Eu-154 & Eu-155 \\
\hline \multicolumn{6}{|c|}{ North Field Project } \\
\hline FSS 103 & -0.06 to 0.04 & -0.02 to 0.36 & -0.06 to 0.04 & -0.02 to 0.01 & -0.01 to 0.15 \\
\hline FSS 109 & -0.05 to 0.03 & 0.04 to 2.07 & -0.05 to 0.00 & -0.03 to 0.01 & 0.00 to 0.05 \\
\hline FSS 113 & -0.06 to 0.02 & 0.18 to 1.36 & -0.04 to 0.04 & -0.01 to 0.02 & 0.01 to 0.10 \\
\hline FSS 114 & -0.05 to 0.07 & 0.21 to 0.42 & -0.05 to 0.02 & -0.02 to 0.01 & -0.05 to 0.12 \\
\hline FSS 115 & -0.04 to 0.03 & 0.14 to 0.48 & -0.04 to 0.01 & -0.02 to 0.02 & -0.04 to 0.08 \\
\hline FSS 116 & -0.02 to 0.02 & 0.20 to 0.30 & -0.05 to 0.07 & -0.02 to 0.02 & -0.01 to 0.12 \\
\hline
\end{tabular}

aRefer to Figures A-13. 
TABLE B-3:

SUMMARIZED RADIONUCLIDE CONCENTRATION

RANGES IN SOIL BY ALPHA SPECTROSCOPY

SEPARATIONS PROCESS RESEARCH UNIT

NISKAYUNA, NEW YORK

\begin{tabular}{|c|c|c|c|c|c|c|c|c|}
\hline \multirow{2}{*}{$\begin{array}{c}\text { Sample } \\
\text { Area }^{\mathbf{a}}\end{array}$} & \multicolumn{7}{|c|}{ Radionuclide Concentration in Soil Samples (pCi/g) } \\
\cline { 2 - 10 } & Am-241 & Pu-238 & Pu-239/240 & U-234 & U-235 & U-238 & Total U $\mathbf{~}^{\text {b }}$ \\
\hline \multicolumn{7}{|c|}{ Level Land Area } \\
\hline FSS 2 & 0.00 to 0.04 & -0.03 to 0.01 & 0.00 to 0.15 & 0.81 to 0.99 & 0.04 to 0.06 & 0.82 to 1.03 & 1.67 to 2.06 \\
\hline FSS 4 & -0.02 to 0.04 & -0.01 to 0.00 & 0.01 to 0.16 & 0.57 to 2.35 & 0.03 to 0.11 & 0.55 to 2.31 & 1.16 to 4.77 \\
\hline FSS 9 & 0.01 to 0.03 & 0.00 to 0.05 & 0.01 to 0.02 & 0.33 to 3.97 & 0.01 to 0.19 & 0.37 to 3.85 & 0.71 to 8.01 \\
\hline FSS 10 & 0.00 to 0.03 & 0.01 to 0.05 & 0.01 to 0.02 & 0.55 to 1.09 & 0.02 to 0.08 & 0.55 to 1.12 & 1.12 to 2.24 \\
\hline FSS 13 & -0.02 to 0.02 & 0.00 to 0.03 & 0.01 to 0.03 & 0.52 to 1.15 & 0.03 to 0.08 & 0.48 to 1.09 & 1.03 to 2.32 \\
\hline FSS 14 & 0.00 to 0.02 & 0.01 to 0.04 & 0.01 to 0.03 & 0.65 to 1.45 & 0.03 to 0.06 & 0.70 to 1.38 & 1.37 to 2.88 \\
\hline
\end{tabular}

aRefer to Figures A-8 and A-9.

${ }^{\text {bTotal }} \mathrm{U}$ is calculated by $\mathrm{U}-234+\mathrm{U}-235+\mathrm{U}-238$. 


\begin{tabular}{|c|c|c|c|c|c|c|c|}
\hline & & $\begin{array}{r}\text { SUMM } \\
\text { RA } \\
\text { SI }\end{array}$ & $\begin{array}{r}\text { IZED RADI } \\
\text { ES IN SOIL } \\
\text { RATIONS I } \\
\text { NISKAY }\end{array}$ & $\begin{array}{l}\text { 3LE B-4: } \\
\text { UCLIDE CC } \\
\text { ALPHA SPI } \\
\text { CESS RESE } \\
\text { JA, NEW YC }\end{array}$ & $\begin{array}{l}\text { ENTRATIO } \\
\text { ROSCOPY } \\
\text { CH UNIT }\end{array}$ & & \\
\hline Sample & & & adionuclide & centration in & Samples (pC & & \\
\hline Area $^{a}$ & Am-241 & Pu-238 & $\mathrm{Pu}-239 / 240$ & U-234 & U-235 & U-238 & Total $\mathrm{U}^{\mathrm{b}}$ \\
\hline & & & Nor & Field Project & & & \\
\hline FSS 103 & 0.00 to 0.01 & 0.00 to 0.02 & 0.00 to 0.02 & 0.74 to 0.93 & 0.03 to 0.05 & 0.77 to 0.95 & 1.56 to 1.91 \\
\hline FSS 109 & -0.05 to 0.03 & 0.01 to 0.03 & 0.00 to 0.03 & 0.66 to 1.23 & -0.08 to 0.22 & 0.66 to 1.23 & 1.24 to 2.56 \\
\hline FSS 113 & -0.06 to 0.04 & 0.00 to 0.01 & 0.01 to 0.03 & 0.69 to 1.03 & -0.06 to 0.19 & 0.69 to 1.03 & 1.32 to 2.21 \\
\hline FSS 114 & -0.09 to 0.05 & 0.01 to 0.02 & 0.00 to 0.02 & 0.69 to 1.38 & -0.20 to 0.19 & 0.69 to 1.38 & 1.40 to 2.95 \\
\hline FSS 115 & -0.01 to 0.01 & -0.01 to 0.01 & 0.00 to 0.04 & 0.76 to 1.11 & 0.03 to 0.06 & 0.81 to 0.97 & 1.61 to 2.11 \\
\hline FSS 116 & -0.09 to 0.04 & 0.00 to 0.02 & 0.01 to 0.02 & 0.79 to 1.49 & -0.05 to 0.14 & 0.79 to 1.49 & 1.61 to 3.10 \\
\hline
\end{tabular}

aRefer to Figures A-13.

${ }^{\text {b} T o t a l ~} \mathrm{U}$ is calculated by U-234 + U-235 + U-238 


\begin{tabular}{|c|c|c|c|c|c|c|c|c|c|c|c|c|}
\hline \multirow{3}{*}{$\begin{array}{l}\text { Sample } \\
\text { ID }^{\mathrm{a}}\end{array}$} & \multicolumn{11}{|c|}{$\begin{array}{c}\text { TABLE B-5: } \\
\text { CONCENTRATIONS OF CHEMICALS IN SOIL SAMPLES } \\
\text { SEPARATIONS PROCESS RESEARCH UNIT } \\
\text { NISKAYUNA, NEW YORK }\end{array}$} & \\
\hline & \multicolumn{12}{|c|}{ Contaminant of Concern $(\mathrm{mg} / \mathrm{kg})$} \\
\hline & $\mathrm{Sb}$ & As & Cd & $\mathrm{Cr}$ & Co & $\mathrm{Cu}$ & $\mathbf{P b}$ & $\mathrm{Hg}$ & Ag & $\mathbf{T 1}$ & $\mathbf{V}$ & $\mathrm{Zn}$ \\
\hline \multicolumn{13}{|l|}{ FSS 1} \\
\hline S007 & $1.4 \mathrm{U}^{\mathrm{b}}$ & $25.7 \mathrm{~J}$ & $0.1 \mathrm{~J}^{\mathrm{c}}$ & 7.5 & 2.2 & $49.0 \mathrm{~J}$ & 8.8 & $0.07 \mathrm{~J}$ & $0.9 \mathrm{U}$ & $1.9 \mathrm{U}$ & 13.3 & $46.8 \mathrm{UJ}$ \\
\hline S008 & $0.5 \mathrm{~J}$ & $58.7 \mathrm{~J}$ & $0.2 \mathrm{~J}$ & 13.5 & 6.8 & $43.4 \mathrm{~J}$ & 47.8 & $0.11 \mathrm{~J}$ & $0.9 \mathrm{U}$ & $1.9 \mathrm{U}$ & 66.2 & $65.9 \mathrm{~J}$ \\
\hline S009 & $1.5 \mathrm{UJ}$ & $12.7 \mathrm{~J}$ & $0.2 \mathrm{~J}$ & 13.6 & 5.5 & $53.5 \mathrm{~J}$ & 37.6 & $0.10 \mathrm{~J}$ & $1.0 \mathrm{U}$ & $2.0 \mathrm{U}$ & 94.3 & $80.4 \mathrm{~J}$ \\
\hline S010 & $1.1 \mathrm{UJ}$ & $11.6 \mathrm{~J}$ & 0.2 & 23.4 & 14.5 & $28.8 \mathrm{~J}$ & 20.2 & $0.05 \mathrm{~J}$ & $0.7 \mathrm{U}$ & $1.5 \mathrm{U}$ & 30.3 & $67.6 \mathrm{~J}$ \\
\hline S011 & $1.3 \mathrm{UJ}$ & $7.0 \mathrm{~J}$ & 0.4 & 12.0 & 7 & $46.5 \mathrm{~J}$ & 17.5 & $0.07 \mathrm{~J}$ & $0.8 \mathrm{U}$ & $1.7 \mathrm{U}$ & 49.6 & $288 \mathrm{~J}$ \\
\hline S012 & $1.2 \mathrm{UJ}$ & $20.6 \mathrm{~J}$ & 0.3 & 24.4 & 17.3 & $54.8 \mathrm{~J}$ & 20.9 & $0.05 \mathrm{~J}$ & $0.8 \mathrm{U}$ & $1.6 \mathrm{U}$ & 31.3 & 113 \\
\hline \multicolumn{13}{|l|}{ FSS 4} \\
\hline S019 & $1.1 \mathrm{~B}^{\mathrm{d} J}$ & 16 & $0.3 \mathrm{BJ}$ & 14 & 9.2 & 29 & 16 & 0.065 & $1 \mathrm{BJ}$ & $0.97 \mathrm{U}$ & 30 & 69 \\
\hline S020 & $1.3 \mathrm{BJ}$ & 6.9 & $0.23 \mathrm{BJ}$ & 15 & 13 & 28 & 17 & 0.041 & $0.26 \mathrm{BJ}$ & $0.95 \mathrm{U}$ & 22 & 69 \\
\hline S021 & $0.49 \mathrm{BJ}$ & 7.1 & $0.27 \mathrm{BJ}$ & 16 & 12 & 31 & 19 & 0.043 & $0.12 \mathrm{U}$ & $0.96 \mathrm{U}$ & 27 & 82 \\
\hline S022 & $0.29 \mathrm{UJ}$ & 5.1 & $0.17 \mathrm{BJ}$ & 12 & 7.5 & 21 & 12 & 0.041 & $0.24 \mathrm{BJ}$ & $0.95 \mathrm{U}$ & 19 & 70 \\
\hline S023 & $1.2 \mathrm{BJ}$ & 8.9 & $0.25 \mathrm{BJ}$ & 18 & 14 & 31 & 17 & 0.034 & $0.29 \mathrm{BJ}$ & $0.94 \mathrm{U}$ & 27 & 67 \\
\hline $\mathrm{S} 024$ & $1.4 \mathrm{BJ}$ & 8.9 & $0.28 \mathrm{BJ}$ & 19 & 16 & 35 & 22 & 0.047 & $0.34 \mathrm{BJ}$ & $0.95 \mathrm{U}$ & 32 & 88 \\
\hline \multicolumn{13}{|l|}{ FSS 10} \\
\hline S039 & $0.99 \mathrm{BJ}$ & 4 & $0.99 \mathrm{BJ}$ & 12 & 7.2 & 18 & 10 & 0.033 & $0.16 \mathrm{BJ}$ & $1.4 \mathrm{U}$ & 17 & $54 \mathrm{~J}$ \\
\hline S040 & $1.2 \mathrm{~J}$ & 21 & 1.4 & 12 & 11 & 31 & 13 & 0.033 & $0.05 \mathrm{U}$ & $1.3 \mathrm{U}$ & 22 & $59 \mathrm{~J}$ \\
\hline S041 & $1.3 \mathrm{~J}$ & 13 & 1.6 & 19 & 16 & 39 & 20 & 0.049 & $0.052 \mathrm{U}$ & $1.4 \mathrm{U}$ & 24 & $81 \mathrm{~J}$ \\
\hline S042 & $1.2 \mathrm{~J}$ & 8.7 & 1.6 & 18 & 13 & 33 & 19 & 0.054 & $0.052 \mathrm{U}$ & $1.4 \mathrm{U}$ & 32 & $72 \mathrm{~J}$ \\
\hline S043 & $0.83 \mathrm{BJ}$ & 5.7 & $1.1 \mathrm{BJ}$ & 14 & 9.3 & 19 & 25 & 0.091 & $0.059 \mathrm{U}$ & $1.6 \mathrm{U}$ & 26 & $61 \mathrm{~J}$ \\
\hline S044 & $0.87 \mathrm{BJ}$ & 5.4 & $1.2 \mathrm{BJ}$ & 13 & 8.2 & 21 & 23 & 0.082 & $0.059 \mathrm{U}$ & $1.6 \mathrm{U}$ & 25 & $65 \mathrm{~J}$ \\
\hline
\end{tabular}




\begin{tabular}{|c|c|c|c|c|c|c|c|c|c|c|c|c|}
\hline & & & $\begin{array}{r}\text { NCEN } \\
\text { SE }\end{array}$ & $\begin{array}{l}\mathbf{R A} \\
\mathbf{R A}\end{array}$ & $\begin{array}{l}\text { NS O } \\
\text { NS I } \\
\text { SKAY }\end{array}$ & $\begin{array}{l}3 \text { LE } \\
\text { HEI } \\
\text { CES } \\
\text { JA, } 1\end{array}$ & $\begin{array}{l}\text { CALS } \\
\text { LESE } \\
\text { W YO }\end{array}$ & $\begin{array}{l}\text { N SOIL } \\
\text { RCH UN } \\
\text { K }\end{array}$ & $\begin{array}{l}\text { MPLES } \\
\mathbf{T}\end{array}$ & & & \\
\hline Sample & & & & & Conta & lant & Conce & l $(\mathrm{mg} / \mathrm{kg}$ & & & & \\
\hline $\mathbf{I D}^{\mathrm{a}}$ & $\mathrm{Sb}$ & As & Cd & $\mathrm{Cr}$ & Co & $\mathrm{Cu}$ & $\mathrm{Pb}$ & $\mathrm{Hg}$ & Ag & T1 & $\mathbf{V}$ & $\mathrm{Zn}$ \\
\hline FSS 9 & & & & & & & & & & & & \\
\hline S045 & $1.7 \mathrm{NJ}^{\mathrm{e}}$ & 170 & 1.4 & 15 & 12 & 46 & 38 & 0.065 & $0.047 \mathrm{U}$ & $1.3 \mathrm{U}$ & 22 & $78 \mathrm{~N}$ \\
\hline S046 & $1.4 \mathrm{~J}$ & 13 & $1.2 \mathrm{BJ}$ & 18 & 14 & 53 & 38 & 0.076 & $0.055 \mathrm{U}$ & $1.5 \mathrm{U}$ & 35 & $100 \mathrm{~J}$ \\
\hline S047 & $1.1 \mathrm{BJ}$ & 7.6 & $0.88 \mathrm{BJ}$ & 16 & 12 & 33 & 15 & 0.036 & $0.047 \mathrm{U}$ & $1.3 \mathrm{U}$ & 21 & $74 \mathrm{~J}$ \\
\hline S048 & $1.2 \mathrm{BJ}$ & 7.3 & 1.4 & 11 & 9 & 42 & 18 & 0.032 & $0.052 \mathrm{U}$ & $0.7 \mathrm{U}$ & 17 & $120 \mathrm{~J}$ \\
\hline S049 & $0.3 \mathrm{UJ}$ & 4.9 & $0.35 \mathrm{BJ}$ & 2.6 & 2 & 1.7 & 2.7 & $0.006 \mathrm{BJ}$ & $0.044 \mathrm{U}$ & $0.59 \mathrm{U}$ & 4.5 & $13 \mathrm{~J}$ \\
\hline S050 & $1 \mathrm{BJ}$ & 12 & $1.1 \mathrm{BJ}$ & 16 & 12 & 42 & 20 & 0.043 & $0.053 \mathrm{U}$ & $1.4 \mathrm{U}$ & 30 & $76 \mathrm{~J}$ \\
\hline
\end{tabular}

aRefer to Figure A-10.

bU=Compound was analyzed for but not detected. The associated numerical value is the estimated sample quantitation limit which is included and corrected for dilution and percent moisture.

$\mathrm{cJ}=$ Indicates an estimated value. This flag is used when estimating a concentration for tentatively identified compounds where a 1:1 response is assumed or when the mass spectral data indicate the presence of a compound that meets the identification criteria but the result is less than the specified detection limit but greater than zero.

$\mathrm{dB}=$ Value was less than the CRDL (Contract Required Detection Limit) or RRL (Required Reporting Limit) specified, but greater than or equal to the IDL (Instrument Detection Limit)/MDL (Method Detection Limit)

$\mathrm{e} N$ = Spiked sample recovery not within control limits. A post spike is analyzed for all ICP analyses with the matrix spike or spike duplicate fail and the native sample concentration is less than four times the spike added concentration. 


\begin{tabular}{|c|c|c|c|c|c|c|c|c|c|c|c|c|}
\hline & & & $\begin{array}{r}\text { RCRA S } \\
\text { SE }\end{array}$ & $\begin{array}{l}\text { IPI } \\
\text { RA }\end{array}$ & $\begin{array}{l}\text { FOR } \\
\text { NS I } \\
\text { SKA }\end{array}$ & $\begin{array}{l}3 \mathrm{LE} \\
\mathrm{IEM} \\
\mathrm{CEE} \\
\mathrm{JA}, \mathrm{I}\end{array}$ & $\begin{array}{l}\text { LS } \\
\text { LESI } \\
\text { W Y }\end{array}$ & $\begin{array}{l}\text { SOIL S } \\
\text { RCH UI } \\
\text { JK }\end{array}$ & $\begin{array}{l}\text { MPLES } \\
\mathrm{T}\end{array}$ & & & \\
\hline Sample & & & & & Cont: & lant & Conc & $(\mathrm{mg} / \mathrm{k}$ & & & & \\
\hline ID $^{\mathrm{a}}$ & $\mathrm{Sb}$ & As & Cd & $\mathrm{Cr}$ & Co & $\mathrm{Cu}$ & $\mathrm{Pb}$ & $\mathrm{Hg}$ & Ag & T1 & $\mathbf{V}$ & $\mathrm{Zn}$ \\
\hline FSS 14 & & & & & & & & & & & & \\
\hline S076 & $1.1 \mathrm{~B}^{\mathrm{b}} \mathrm{J}^{\mathrm{c}}$ & 24 & $0.21 \mathrm{BJ}$ & 10 & 6.1 & 28 & 30 & 0.11 & $0.13 \mathrm{BJ}$ & $0.42 \mathrm{U}^{\mathrm{d}}$ & 26 & 120 \\
\hline S077 & $1.3 \mathrm{~J}$ & 5.7 & $0.01 \mathrm{BJ}$ & 19 & 13 & 27 & 15 & 0.037 & $0.14 \mathrm{U}$ & $0.9 \mathrm{U}$ & 31 & 79 \\
\hline S078 & $1.1 \mathrm{~J}$ & 6.7 & $0.11 \mathrm{BJ}$ & 19 & 13 & 29 & 16 & 0.056 & $0.12 \mathrm{U}$ & $0.82 \mathrm{U}$ & 24 & 77 \\
\hline S079 & $0.59 \mathrm{BJ}$ & 5 & $0.11 \mathrm{BJ}$ & 11 & 8.9 & 21 & 12 & 0.045 & $0.12 \mathrm{U}$ & $0.8 \mathrm{U}$ & 17 & 61 \\
\hline FSS 13 & & & & & & & & & & & & \\
\hline S080 & $1.0 \mathrm{BJ}$ & 5.9 & $0.3 \mathrm{BJ}$ & 14 & 8.3 & 27 & 47 & 0.21 & $0.13 \mathrm{U}$ & $0.83 \mathrm{U}$ & 29 & 79 \\
\hline S081 & $0.79 \mathrm{BJ}$ & 6.8 & $0.13 \mathrm{BJ}$ & 16 & 8.9 & 27 & 20 & $0.015 \mathrm{BJ}$ & $0.14 \mathrm{U}$ & $0.47 \mathrm{U}$ & 20 & 64 \\
\hline S082 & $0.92 \mathrm{BJ}$ & 4.5 & $0.29 \mathrm{BJ}$ & 17 & 7.4 & 26 & 40 & 0.089 & $0.14 \mathrm{U}$ & $0.46 \mathrm{U}$ & 49 & 77 \\
\hline S083 & $0.74 \mathrm{BJ}$ & 4.3 & $0.22 \mathrm{BJ}$ & 13 & 7.2 & 13 & 23 & 0.1 & $0.17 \mathrm{U}$ & $0.56 \mathrm{U}$ & 55 & 57 \\
\hline S084 & $1.5 \mathrm{BJ}$ & 7.3 & $0.44 \mathrm{BJ}$ & 19 & 12 & 50 & 34 & 1.4 & $0.36 \mathrm{BJ}$ & $0.64 \mathrm{U}$ & 79 & 120 \\
\hline S085 & $0.75 \mathrm{BJ}$ & 4.6 & $0.12 \mathrm{BJ}$ & 12 & 8.1 & 22 & 15 & 0.17 & $0.15 \mathrm{U}$ & $0.48 \mathrm{U}$ & 29 & 58 \\
\hline S086 & $1.5 \mathrm{~J}$ & 4.7 & 1.1 & 11 & 4.8 & 22 & 38 & 0.18 & $0.13 \mathrm{U}$ & $0.41 \mathrm{U}$ & 14 & 68 \\
\hline S087 & $0.67 \mathrm{BJ}$ & 5.3 & $0.14 \mathrm{BJ}$ & 12 & 8.3 & 25 & 15 & 0.23 & $0.12 \mathrm{U}$ & $0.82 \mathrm{U}$ & 24 & 51 \\
\hline S088 & $1.0 \mathrm{BJ}$ & 7.1 & 0.62 & 16 & 12 & 37 & 18 & 0.59 & $0.13 \mathrm{U}$ & $0.85 \mathrm{U}$ & 36 & 72 \\
\hline
\end{tabular}

aRefer to Figure A-11

bB = Value was less than the CRDL (Contract Required Detection Limit) or RRL (Required Reporting Limit) specified, but greater than or equal to the IDL (Instrument Detection Limit)/MDL (Method Detection Limit)

c J Indicates an estimated value. This flag is used when estimating a concentration for tentatively identified compounds where a 1:1 response is assumed or when the mass spectral data indicate the presence of a compound that meets the identification criteria but the result is less than the specified detection limit but greater than zero.

$\mathrm{d} \mathrm{U}=$ Compound was analyzed for but not detected. The associated numerical value is the estimated sample quantitation limit which is included and corrected for dilution and percent moisture. 


\section{APPENDIX C MAJOR INSTRUMENTATION}


The display of a specific product is not to be construed as an endorsement of the product or its manufacturer by the author or his employer.

\section{C.1 SCANNINg AND MEASUREMENT InSTRUMENT/Detector Combinations}

Ludlum Scintillation Detector Model SPA-3, Crystal: 2-in. x 2-in. (Ludlum Measurements, Inc., Sweetwater, TX)

Coupled to:

Ludlum Ratemeter-Scaler Model 2221 (Ludlum Measurements, Inc., Sweetwater, TX)

Coupled to:

Trimble GeoXH Receiver and Data Logger (Trimble Navigation Limited, Sunnyvale, CA)

Bicron Field Instrument Detector for Low Energy Radiation (FIDLER) Model G5 (Bicron

Corporation, Newburg, $\mathrm{OH}$ )

Coupled to:

Ludlum Ratemeter-Scaler Model 2221 (Ludlum Measurements, Inc., Sweetwater, TX)

Coupled to:

Trimble GeoXH Receiver and Data Logger (Trimble Navigation Limited, Sunnyvale, CA)

High Purity Germanium Detector Model GR3819 (Canberra, Meriden, CT)

Used in conjunction with:

In-Situ Object Counting System (ISOCS) Calibration Software (Canberra, Meriden, CT) and

Inspector -2000 Multichannel Analyzer with Dell Workstation

\section{C.2 LABORATORY ANALYTICAL INSTRUMENTATION}

High-Purity Extended Range Intrinsic Detector CANBERRA/Tennelec Model No:

ERVDS30-25195 (Canberra, Meriden, CT)

Used in conjunction with:

Lead Shield Model G-11 (Nuclear Lead, Oak Ridge, TN), Apex Gamma Software (Canberra, Meriden, CT) and Multichannel Analyzer with Dell Workstation

High-Purity Extended Range Intrinsic Detector Model No. GMX-45200-5 (AMETEK/ORTEC, Oak Ridge, TN)

Used in conjunction with:

Lead Shield Model SPG-16-K8 (Nuclear Data), Apex Gamma Software (Canberra, Meriden, CT) and Multichannel Analyzer with Dell Workstation

High-Purity Germanium Detector Model GMX-30-P4, 30\% Eff. (AMETEK/ORTEC, Oak Ridge, $\mathrm{TN}$ )

Used in conjunction with:

Lead Shield Model G-16 (Gamma Products, Palos Hills, IL), Apex Gamma Software (Canberra, Meriden, CT) and Multichannel Analyzer with Dell Workstation 
Alpha Spectroscopy System with 7401VR Spectrometers (Canberra, Meriden, CT) and TC256 Spectrometers (Tennelec/Canberra, Meriden, CT), Apex Alpha Software (Canberra, Meriden, CT)and Multichannel Analyzer with Dell Workstation 


\section{APPENDIX D \\ SURVEY AND ANALYTICAL PROCEDURES}




\section{D.1 Project Health AND SAFETY}

The survey and sampling procedures were evaluated to ensure that any hazards inherent to the procedures themselves were addressed in current job hazard analyses (JHAs). All survey and laboratory activities were conducted in accordance with ORISE health and safety and radiation protection procedures.

Pre-survey activities included an overview of potential health and safety issues. SPRU representatives provided site-specific safety awareness training for each individual ORISE survey effort. In-process and verification surveys were performed according to the ORISE generic health and safety plan, site-specific Integrated Safety Management (ISM) pre-job hazard checklist, and safety procedures discussed during the on-site training.

\section{D.2 QuAlity Assurance}

Analytical and field survey activities were conducted in accordance with procedures from the following ORAU and ORISE documents:

- $\quad$ Survey Procedures Manual (ORISE 2008b)

- Laboratory Procedures Manual (ORISE 2010e)

- Quality Program Manual (ORAU 2009)

The procedures contained in these manuals were developed to meet the requirements of 10 CFR 830 Subpart A, Quality Assurance Requirements, Department of Energy Order 414.1C, Quality Assurance, and the U.S. Nuclear Regulatory Commission, Quality Assurance Manual for the Office of Nuclear Material Safety and Safeguards, and contain measures to assess processes during their performance.

Quality control procedures include:

- Daily instrument background and check-source measurements to confirm that equipment operation is within acceptable statistical fluctuations.

- Participation in Mixed Analyte Performance Evaluation Program (MAPEP), National Institute for Standards and Technology (NIST) Radiochemistry Intercomparison Program (NRIP), and Intercomparison Testing Program (ITP) Laboratory Quality 
Assurance Programs.

- Training and certification of all individuals performing procedures.

- Periodic internal and external audits.

\section{D.3 CALIBration}

Calibration of all field and laboratory instrumentation was based on standards/sources, traceable to NIST, when such standards/sources were available. In cases where they were not available, standards of an industry-recognized organization were used.

\section{D.4 Survey Procedures}

\section{D.4.1 Surface Scans}

Scans for elevated gamma radiation were performed by passing the detector slowly over the surface. The distance between the detector and surface was maintained at a nominal of about 1 to 5 centimeters $(\mathrm{cm})$. NaI scintillation detectors were coupled to GPS units that enabled real-time recording of position in one-second intervals. Identification of elevated radiation levels was based on increases in the audible signal from the instrument. Positioning data files were downloaded from field data loggers for plotting using commercially available software (http://trl.trimble.com/docushare/dsweb/Get/Document261826/GeoExpl2005 100A GSG ENG.pdf).

The scan minimum detectable concentrations (MDCs) for the $\mathrm{NaI}$ scintillation detector for the contaminants of concern in surface soil were obtained directly from NUREG- $1507^{1}$ when available or estimated using the calculation approach described in NUREG-1507. A typical NaI 2-inch by 2-inch detector MDC is $6.4 \mathrm{pCi} / \mathrm{g}$ for cesium-137. Audible increases in the activity rate are investigated by ORISE. It is standard procedure for ORISE staff to pause and investigate any locations where gamma radiation is distinguishable from background levels.

${ }^{1}$ NUREG-1507. Minimum Detectable Concentrations With Typical Radiation Survey Instruments for Various Contaminants and Field Conditions. U.S. Nuclear Regulatory Commission. Washington, DC; June 1998. 


\section{D.4.2 Soil Sampling}

Approximately 0.5 to 1 kilogram of soil was collected at each sample location. Collected samples were placed in plastic bags, sealed, and labeled in accordance with ORISE survey procedures.

\section{D.5 RADIOLOGICAL ANALYSIS}

\section{D.5.1 Detection Limits}

Detection limits, referred to as MDC, were based on 3 plus 4.65 times the standard deviation of the background count $\left[3+\left(4.65(\mathrm{BKG})^{1 / 2}\right)\right]$. Because of variations in background levels, measurement efficiencies, and contributions from other radionuclides in samples, the detection limits differ from sample to sample and instrument to instrument.

\section{D.5.2 Alpha Spectroscopy}

Soil samples were homogenized then dissolved by a combination of potassium hydrogen fluoride and pyrosulfate fusions. The fusion cakes are dissolved and all alpha emitters are co-precipitated on barium sulfate. The barium sulfate is re-dissolved and the COC is separated from the other actinides by extraction chromatography using Eichrom resins, co-precipitated with a cerium fluoride carrier, and analyzed using ion implanted detectors, alpha spectrometers, and multichannel analyzer.

An alpha spectroscopy detector system calculates an MDC for each individual isotope per sample based on the detector background, counting efficiency, yield, and quantity. An MDC is printed out with each sample results. The typical MDC for a 1,000-minute count time was $0.02 \mathrm{pCi} / \mathrm{g}$. Total absorption peaks (TAPs) used for determining the activities of radionuclides of concern and the typical associated MDCs were:

\begin{tabular}{|c|c|c|}
\hline Radionuclide $^{\mathrm{a}}$ & TAP $(\mathbf{M e V})$ & MDC $(\mathbf{p C i} / \mathbf{g})$ \\
\hline $\mathrm{Am}-241$ & 5.486 & 0.05 \\
\hline $\mathrm{Pu}-238$ & 5.499 & 0.04 \\
\hline $\mathrm{Pu}-239 / 240$ & 5.155 & 0.02 \\
\hline $\mathrm{U}-234$ & 4.775 & 0.02 \\
\hline $\mathrm{U}-235$ & 4.396 & 0.02 \\
\hline $\mathrm{U}-238$ & 4.190 & 0.10 \\
\hline
\end{tabular}

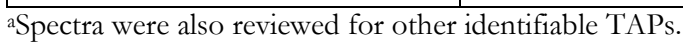




\section{D.5.3 Gamma Spectroscopy}

Samples of soil were dried, mixed, crushed, and/or homogenized as necessary, and a portion sealed in a 0.5 -liter Marinelli beaker or other appropriate container. The quantity placed in the beaker was chosen to reproduce the calibrated counting geometry. Net material weights were determined and the samples counted using intrinsic germanium detectors coupled to a pulse height analyzer system. Background and Compton stripping, peak search, peak identification, and concentration calculations were performed using the computer capabilities inherent in the analyzer system. All TAPs associated with the radionuclides of concern were reviewed for consistency of activity. Total absorption peaks used for determining the activities of radionuclides of concern and the typical associated MDCs for a one-hour count time were:

\begin{tabular}{|c|c|c|}
\hline Radionuclide $^{\mathrm{a}}$ & TAP (MeV) & MDC (pCi/g) \\
\hline Cs-137 & 0.662 & 0.05 \\
\hline Co-60 & 1.170 & 0.06 \\
\hline Eu-152 & 0.344 & 0.30 \\
\hline Eu-154 & 0.723 & 0.30 \\
\hline Eu-155 & 0.105 & 0.14 \\
\hline
\end{tabular}

\section{D.5.4 Uncertainties}

The uncertainties associated with the analytical data presented in the tables of this report represent the total propagated uncertainties for those data. These uncertainties were calculated based on both the gross sample count levels and the associated background count level. 